\title{
Analyzing Utilization of Biomass in Combined Heat and Power and Combined Cooling, Heating, and Power Systems
}

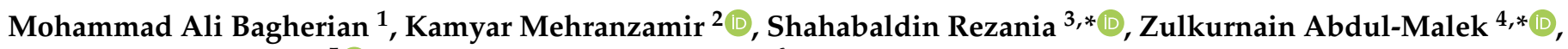 \\ Amin Beiranvand Pour ${ }^{5}$ (i) and Seyed Morteza Alizadeh ${ }^{6}$
}

1 Ecole Polytechnique de Louvain, Université Catholique de Louvain, 1348 Louvain-la-Neuve, Belgium; mohammad.bagherian@student.uclouvain.be

2 Department of Electrical and Electronic Engineering, Faculty of Science and Engineering, University of Nottingham Malaysia, Jalan Broga, Semenyih 43500, Malaysia;

Kamyar.mehranzamir@nottingham.edu.my

3 Department of Environment and Energy, Sejong University, Seoul 05006, Korea

4 Institute of High Voltage \& High Current, School of Electrical Engineering, Faculty of Engineering, Universiti Teknologi Malaysia, Johor Bahru 81310, Malaysia

5 Institute of Oceanography and Environment (INOS), Universiti Malaysia Terengganu (UMT), Kuala Nerus 21030, Malaysia; beiranvand.pour@umt.edu.my

6 School of Electrical Engineering and Industrial Automation, Engineering Institute of Technology, Melbourne Campus, Victoria 3000, Australia; morteza.alizadeh@eit.edu.au

* Correspondence: shahab.rezania@sejong.ac.kr (S.R.); zulkurnain@utm.my (Z.A.-M.)

\section{check for}

updates

Citation: Bagherian, M.A.; Mehranzamir, K.; Rezania, S. Abdul-Malek, Z.; Pour, A.B.; Alizadeh, S.M. Analyzing Utilization of Biomass in Combined Heat and Power and Combined Cooling, Heating, and Power Systems. Processes 2021, 9, 1002. https:// doi.org/10.3390/pr9061002

Academic Editors: Beatrice Castellani and Andrea Nicolini

Received: 20 April 2021

Accepted: 31 May 2021

Published: 5 June 2021

Publisher's Note: MDPI stays neutral with regard to jurisdictional claims in published maps and institutional affiliations.

Copyright: (c) 2021 by the authors. Licensee MDPI, Basel, Switzerland. This article is an open access article distributed under the terms and conditions of the Creative Commons Attribution (CC BY) license (https:// creativecommons.org/licenses/by/ $4.0 /)$.
Abstract: Nowadays, ever-increasing energy demands and the depletion of fossil fuels require efficient and environmentally friendly technologies for energy generation. In this context, energy systems integration makes for a very strong proposition since it results in energy saving, fuel diversification, and the supply of cleaner energy. To this end, it is of the utmost importance to realize the current developments in this field and portray the state of the art of renewable generation in integrated energy systems. This review evaluates the utilization of bioenergy in cogeneration and trigeneration systems. The statistical reports of bioenergy and combined heat and power deployments in 28 countries of the European Union are discussed. Then, the most common research objectives of biomass-fueled combined heat and power systems are classified into three primary performance analyses, namely, energy and exergy analysis, thermo-economic optimization, and environment assessment. The influencing parameters of biomass utilization on each type of assessment are discussed, and the basic principles for carrying out such analyses in energy systems are explained. It is illustrated that the properties of feedstock, selection of appropriate conversion technology, associated costs with the biomass-to-bioenergy process, and sustainability of biomass are the primary influencing factors that could significantly affect the results of each assessment.

Keywords: integrated energy system (IES); combined heat and power (CHP); combined cooling; heating and power (CCHP); energy and exergy analysis; thermo-economic optimization

\section{Introduction}

Over time, the climate system experiences unforced and irregular variations (climate change), which may affect the climate of a certain area or the globe in many forms, such as wind or sea surface temperature [1]. Climate change often appears as a new weather pattern that might last for as long as a decade to a million years, and it can be caused by both natural incidence and human-induced activities. Unfortunately, in today's world, human-induced activities are overtaking naturally occurring ones and enforcing the climate system to observe more energy from the sun, which correspondingly results in increasing global temperature or, as famously known, "global warming" [2]. The concept of global warming is an important aspect of climate change for which human activities, including the excess emission of greenhouse gases (GHG), deforestation, $\mathrm{CO}_{2}$ and aerosols, are the 
primary causes [3]. After the industrial revolution, the discovery of fossil fuels and their potential in almost every sector resulted in a significant increase in GHG concentration levels. The emission of carbon dioxide $\left(\mathrm{CO}_{2}\right)$ alone is responsible for over $66 \%$ of this increase, reaching 407.8 parts per million (ppm) in 2018, 1.5 times that of the concentration level in 1750 [4]. The primary attributes of this emission are the consumption of fossil fuels in different sectors (95\%), and the production of cement for various applications (4.5\%) [5]. In the energy sector, fossil fuels are still considered to be the main source of generation due to lower price, political relations, and weaker energy efficiency efforts (Figure 1) [6]. Apart from the fact that the majority of countries still promote the use of fossil energy, over the past 10 years, substantial contributions have been made by developed countries, particularly the European Union (EU-28), to replace conventional methods of generation with sustainable systems and promote renewable energy sources (RESs) instead. To this end, the share of fossil fuels in power production witnessed a $1.7 \%$ reduction in value, while renewable generation was increased by over $4 \%$ between 2010 and 2018 [7,8]. Taking the growing consumption of energy and the depletion of non-renewable energy sources into account, countries are required to promote and develop sustainable energy systems that utilize renewable energy sources not just in electricity generation, but also in other sectors, such as heating and cooling [9].

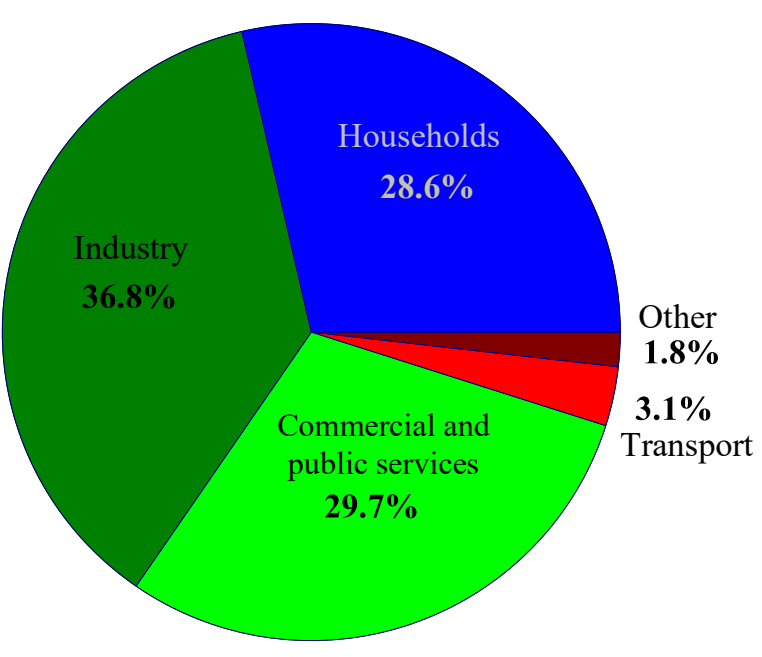

(a)

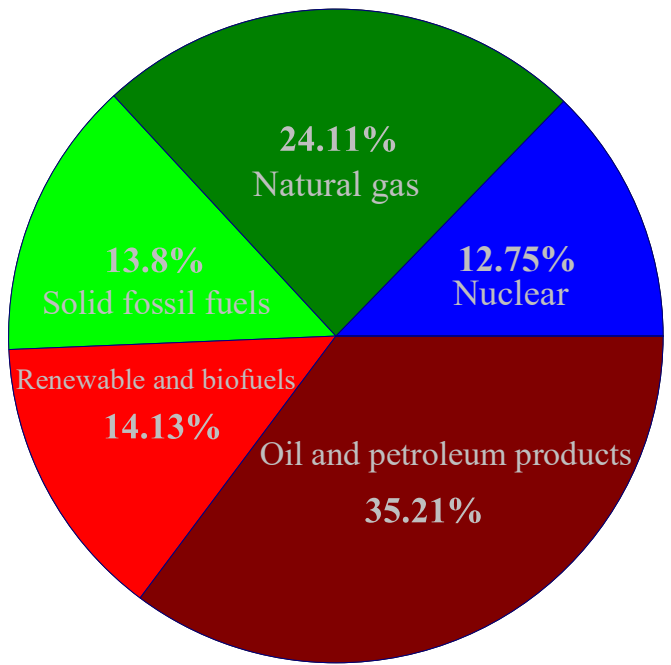

(b)

Figure 1. Classification of final electricity consumption in 2017 (a) by sector and (b) primary energy consumption in 2017 by fuel type in the case of EU-28.

Biomass is among the most available, renewable energy sources on the planet. This non-fossilized and biologically degradable material is either created from plants, species, and micro-organisms, or it can be derived from products, by-products, and wastes [10]. There are various types of biomass feedstocks available in Europe, including dedicated crops and wastes and residues. Sugar crops, oil crops, starch crops, algae and aquatic biomass and lignocellulosic crops are in the dedicated crops category, while waste gases, organic residues, oil-based residues and lignocellulosic residues are in the wastes and residues category. Bioenergy is defined as the energy derived from the conversion of biomass, where biomass can be used directly as fuel or processed into liquid and gaseous forms. It is one of the most versatile RES that can be used in different forms (solid, liquid, and gaseous) for different applications (power, heat, and transportation). To this end, its application has seen a significant increase, particularly in the heating sector. In Europe, the installed capacity of bioenergy has expanded by approximately $180 \%$ over the past decade [11,12]. This source of energy is responsible for $9 \%$ and $16 \%$ of total electricity and heat generation, respectively [13]. Today, biomass remains one of the largest and primary RES around the world, due to its wide-spread use, renewability, and 
versatility [14]. In terms of availability and generation rate, solid biomass, particularly woody plants, encompass the largest portion, while biogas and biofuel come second and third, respectively [15]. According to "Bioenergy Europe", woody biomass takes $70 \%$ of all available feedstock for energy generation in EU-28, whereas this value is only $18 \%$ for agricultural biomass and $12 \%$ for bio-waste (Figure 2). Further, this database indicates that the utilization of biomass takes place mostly in the industrial sector for heating purposes. Almost three-quarters of the supplied feedstock was exploited for heating supply and the remaining for electricity generation and transportation fuels [16]. Currently, bioenergy is the first choice of RES in many countries and remains the core of the future energy mix, especially in EU-28. Provided that the bioenergy developments in EU-28 are increasing massively, maintaining economic competitiveness regarding biomass supply and demand mismatches is the primary challenge in this continent. From environmental damages and biodiversity destruction to lack of incentives and regulations, bioenergy requires research attention, financial investments, and firm policies. Over the past 20 years, this source of energy has been considered the most promising solution to the challenges associated with the development of clean generation and a profitable "green energy market" [17].

Solid Biomass 100.296 KTOE

(Growth Rate 2016-17: $+2.30 \%$ )

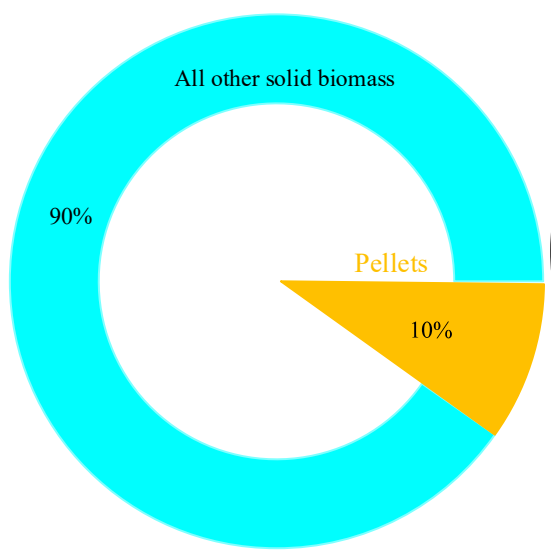

Biogas

$16.826 \mathrm{KTOE}$

(Growth rate 2016-17: $+0.44 \%$ )

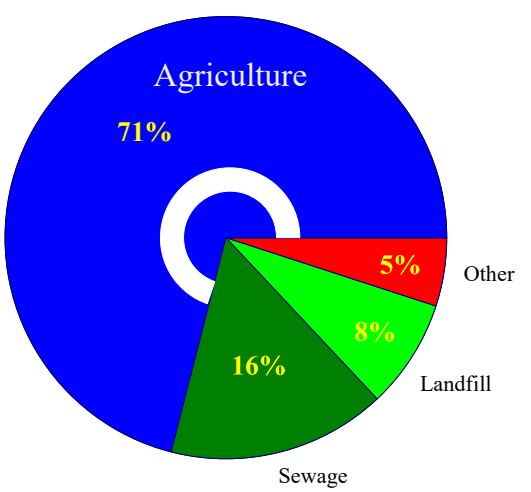

Biofuels 16.492 KTOE

(Growth Rate 2016-17: 9.06\%)

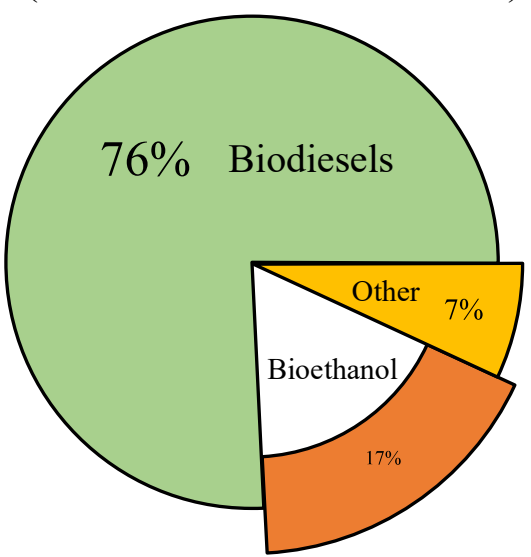

Municipal waste (Renewable) $10.474 \mathrm{KTOE}$

(Growth rate 2016-17: $+3.40 \%$

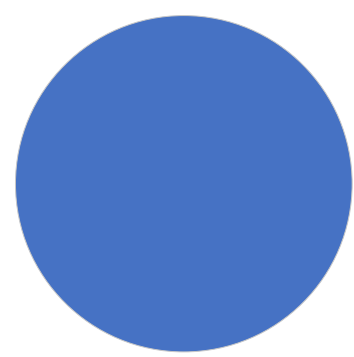

Figure 2. Biomass consumption categorized by type, use, and source in the case of EU-28 in 2017 (total: $144.088 \mathrm{KTOE}$ (million tonnes of oil equivalent)).

The discovery of electricity, and later, its method of generation, revolutionized the world and lives of everyone from different points of view. Starting in the 19th century with rapid developments and progress in electrical science, after almost 200 years, humans 
are still seeking new ways of generating and improving efficiency. At the beginning of the 20th century, it was well known that the large-scale generation of power at a long distance from center of the population is associated with drawbacks and limited efficiency. To this end, both the industry and research communities were urged to design and develop new methods of generation in order to increase the overall efficiency and lower the consumption of primary energy sources. One of the most promising approaches in which these two objectives could be achieved was producing more than one product (syngas and pure hydrogen) or energy forms (heating and cooling) in a power plant. These types of plants were soon recognized as cogeneration, trigeneration, and polygeneration systems. Cogeneration, or combined heat and power (CHP) systems, have received a great deal of attention due to their capability for sequential power and heat generation within a single process $[18,19]$. In the cogeneration process, waste thermal energy can be recovered in order to produce another form of energy or product. Considering a situation where an ignition-based engine drives a generator that produces electricity, with the implementation of a heat exchanger, the waste heat exiting out of the engine in the form of hot exhaust can be captured, and the heat can be recovered to produce steam, hot water, or process heat [20]. This principle of operation differentiates CHP facilities from other centralized power plants, and it allows more efficient utilization of fuel to a point where the overall efficiency can reach up to $90 \%$ [21]. For many industries, organizations, or even real-estate developers, CHP systems can offer seminal opportunities to diminish imported electricity from the grid and decrease fossil fuel consumption. Integrating the power and heating sectors is a promising approach to achieve energy efficiency, fuel diversification, and fewer environmental impacts [22]. The estimated growth potential for cogeneration systems is beyond $120 \mathrm{GW}_{\mathrm{el}}$, which subsequently leads to the reduction of GHG emissions and the improvement of economic competitiveness. Realizing the true capabilities of this approach would ensure the accomplishment of energy transition and climate strategies. There is no doubt that CHPs are associated with higher capital cost and investment; however, these facilities take advantage of better environmental performance, a reliable energy supply, and the reduction in electricity price [23]. Despite the operating advantages, the development of CHP systems offer other financial incentives in most countries; for instance, in the U.K., if the quality of the implemented CHP unit can pass the "CHP Quality Assurance Programme" (CHPQA) requirements, one can benefit from several financial incentives, such as reduction in climate change levy (CCL), enhancement of enhanced capital allowance (ECA), and business rates exemption [24]. Integrating CHPs with renewable technologies or utilizing renewable sources as fuel for an operation has attracted researchers and industries for further developments and investments in this field [25].

Clean energy transition has been the primary goal for the majority of developed countries. As the global energy sector is responsible for over $90 \%$ of $\mathrm{CO}_{2}$ emissions, countries are adopting new concerted policies toward decarbonization and further investments in the renewable energy sector. Significant contributions have been made to support low-emission technologies, such as the development of CHP systems, in order to achieve that goal. In Europe, CHP systems are one of the most important sources of energy and a key player in GHG emissions reduction. Although investment in the energy sector has declined over the past three years, in 2018, over 39\% of the total investment was allocated to low-emission technologies, such as energy integration [26]. Based on the acquired data from EU-28 in 2017, cogeneration was responsible for $11 \%$ of total gross electricity generation, with Denmark having the highest share at $38 \%$. Interestingly, numerous countries have been operating these systems mainly on natural gas and renewables rather than highly pollutant solid fossil fuels and oil. The capability of these systems to adopt different fuel types allow modification of fuel utilization, and consequently, increased the total capacity of these systems over the past decade. Between 2005 and 2017, the total capacity of cogeneration facilities experienced an increase of $16 \%$, whereas the share of this technology in total electricity production remained the same. Moreover, fuel utilization was subjected to a significant adjustment, favoring cleaner production. This increased the share of renewables 
by $18 \%$ and natural gas by $6 \%$, while lessening the fossil fuels contribution by over $20 \%$ (Figure 3) [27,28].

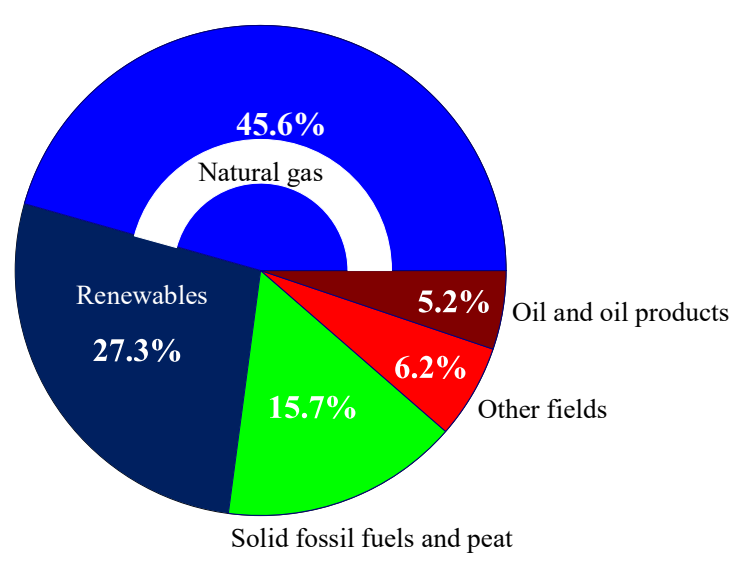

(a)

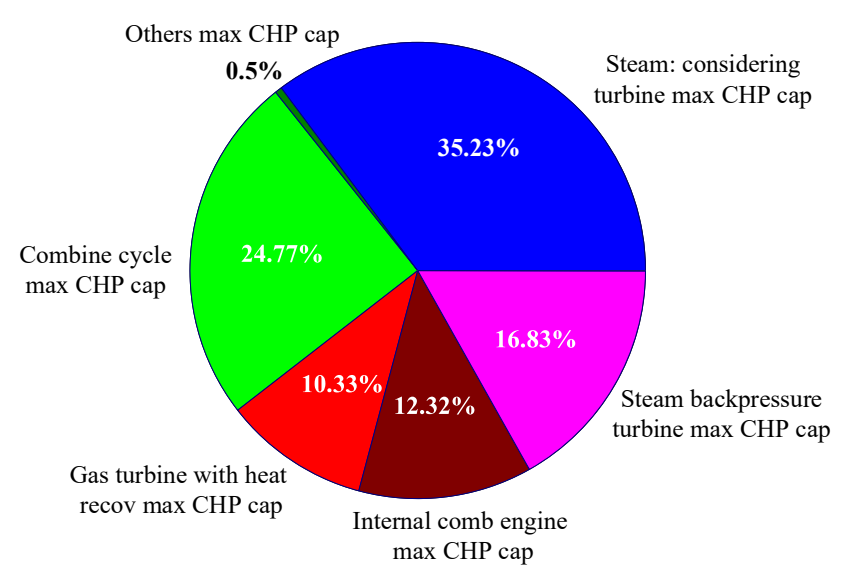

(b)

Figure 3. (a) Percentage of CHP fuel mix in 2017 by type, (b) CHP systems in 2015 by technology (right) in the case of EU-28.

Understanding the need for this study was first grasped by conducting a systematic literature search. Evidently, the majority of studies elaborated on the utilization of multiple RESs or only biomass in cogeneration systems. The summary of preliminary studies in the following section illustrates that the majority of articles persisted to highlight the importance of biomass resources in energy systems and re-evaluate the operation of different configurations.

\subsection{Utilizing Biomass in Micro-CHP Systems}

Biomass gasification can be utilized in fuel cell (FC) systems instead of natural gas. Highly efficient micro-CHPs can be developed by coupling biomass gasification and the hydrogen energy system in order to utilize biomass feedstock in emerging new technologies, such as fuel cell, for energy generation. In this context, Reference [29] reviewed the progress of implementing biomass gasification in Solid Oxide Fuel Cell-CHP (SOFC-CHP) systems. The authors in [29] provided a brief overview of the operation, the current status, and the future perspective of such integration. They considered the developments of micro-CHPs in particular and discussed the operation of different anode materials for this type of configuration. The properties of different biomass resources were pointed out, and the key findings of the handful of references were presented as well. In contrast, Arsalis took a wider approach and included all the available FC types in his study [30]. The author presented a comprehensive review that analyzed the operation of all available FC-CHP units and provided the key findings elaborating on this topic. He overviewed the utilization of alternative fuels and discussed the advantages of using biomass resources in FC-CHP systems. Biomass resources can be used as fuel for any kind of prime mover in CHP units. To evaluate the performance of this RES with different prime mover technologies, the available biomass-based micro-CHP systems were reviewed in Reference [31]. Martinez et al. investigated the employment of RES, particularly biomass and solar, in micro-CHP systems. The authors divided the structure of the paper into two parts in which the first part was dedicated to conversion technologies and their associated advantages and disadvantages, whereas the second part dealt with RES-fueled micro-CHP systems and their operation. The models were classified based on the prime movers' technologies and the implemented RES. A similar approach was taken by Murugan and Horák in Reference [32] in which the operation of different prime movers and their application in the residential sector was discussed and reviewed. Various fuel types for each prime mover were considered, and the potential of biomass resources in micro-CHP units was 
studied. Similar to the previous case, the structure of the paper was divided into two sections in which the first part explained the operation of prime movers in detail and the second part analyzed the performance of micro-CHPs in the residential sector. In Reference [33], apart from the prime mover technologies and their associated characteristics in micro-CHP systems, the application of such plants and the possibility of biomass integration were studied and a comparison was drawn to validate the advantages of microCHPs, compared to conventional methods of generation. Considering the application of biomass gasification in small-scale CHP plants, Reference [34] explained the effects of biomass composition, particle size, and gasifying agents on the gasification process. The developments and current status of such integration were summarized, and the challenges and future perspective of biomass gasification in energy systems were provided. In a similar scale size, another study overviewed the performance of biomass-fired combined cooling, heating, and power (CCHP) plants and analyzed the operation of the systems in terms of the implemented components and key findings [35].

\subsection{Utilizing Biomass in Small- to Large-Scale CHP Plants}

The exploitation of biomass resources in energy systems is often considered in larger scales due to the higher efficiency to investment ratio. Such high-capacity plants are preferable since both industrial and energy sectors deal with high power requirements [36,37]. Although the development of biomass-fueled micro-CHP systems is of interest to many small businesses and real-estate developers, these systems require financial incentives, marketing strategies, and commercial availability across the world. There are several studies that overviewed and discussed the utilization of biomass resources in large-scale energy systems. In one of these cases, chemical looping combustion (CLC) was assumed as a promising solution to emission-related issues. These systems can be employed in multi-generation configurations, such as CHP and CCHP, and can be classified based on the implemented components and the output products. The application of such structure in cogeneration and trigeneration systems was elaborated in Reference [38]. Rajabi et al. [38] explained the operation and discussed the possible inputs and outputs of this system in integration with CHP and CCHP plants. The authors provided the acquired results of several references in order to compare and raise awareness for better decision making and modeling in the future. In a different approach, Malico et al. investigated the current status of biomass consumption in the European industrial sector [14]. The authors focused on bioheat and considered all the available biomass resources and energy conversion methods. The study [14] was concluded by stating the current barriers facing this sector and the utilization of biomass. Malico et al. reviewed the advantages of biomass gasification in tri- and polygeneration facilities [39]. The authors [39] conducted their own case study assessment in which the performance of biomass gasification was evaluated in an existing, natural gas-based trigeneration plant in Lisbon. They investigated the benefits and shortcomings of such integration in terms of environmental and energetic points of view. Further, they suggested opportunities to overcome the barriers in this sector. Another study in Portugal took a wider approach and overviewed the consumption of biomass resources for energy production in the country [40]. Various energy systems were analyzed and the opportunities of biomass integration into cogeneration systems were reviewed. The study was mainly conducted to outline the projection of biomass consumption and the importance of its development in different sectors by governmental and private organizations. The consumption of bioenergy was presented as well, and it was classified based on types of biomass feedstocks. The integration of bioenergy into CHP systems is not always beneficial. Different forms of this RES are associated with several thermodynamic disadvantages and financial drawbacks; for instance, biogas utilization in energy systems is currently not efficient enough to be considered for further development and investment. In this regard, Hosseini and Wahid evaluated the operation of several combustion regimes based on the biogas properties [41]. They considered the implementation of different kinds of energy systems, including cogeneration. The authors 
discussed the flameless combustion of biogas as the best possible option for CHP plants and analyzed the financial feasibility of this method. In recent times, the development of hybrid energy plants, due to their improved efficacy and limited-to-no environmental impacts, has gained considerable attention in developed countries. Configuring different prime mover technologies along with renewable resources has made this type of system an interesting approach toward the energy transition goals. One of the most compelling configurations is the implementation of FC and ignition-based engines in a single structure. This type of system was overviewed thoroughly by Italian researchers, who investigated all the possible integrations of SOFC/GT-CHP plants [42]. They evaluated the performance of such facilities both economically and thermodynamically. Further, the possible fuels for operating these configurations were presented and the benefits of biomass utilization were analyzed.

The main intention of this study is to discuss the bioenergy and combined heat and power deployments in 28 countries of the European Union. This review is structured into three sections in which the preliminary studies, current research objectives, the biomass influencing factor, and the future perspective of biomass integration into co- and trigeneration systems are covered. In Section 1, the most recent contributions on reviewing the current status of biomass utilization for CHP and CCHP generation were realized, and a summary of their key findings was provided. Additionally, the introduction of the study was discussed in Section 1. In Section 2, the primary research objectives are investigated, and the objectives are grouped into three main categories, namely, energy and exergy assessment, thermo-economic assessment, and environmental assessment. All three evaluations are comprehensively explained and the influencing factors in each assessment concerning biomass utilization are mentioned. Finally, in Section 3, a conclusion is drawn and the future perspective of biomass utilization in the energy sector is provided.

\section{Performance Analysis}

Bioenergy implementation in existing energy systems has been the prime focus over the past decade. This is due to the fact that, with clean generation strategies adopted by the vast majority of countries, biomass utilization instead of fossil fuels is the most promising solution to emission-related issues. The accessibility and versatility of this RES are of interest to many industries as well as the energy sector all around the globe. A systematic literature search was carried out to realize the current research trends on CHP and CCHP development as well as biomass utilization in such systems. The search was conducted based on the use of primary keywords in titles or abstracts, including "CHP", "CCHP", "Renewable Energy Sources", "Biomass", "Biomass Gasification", "Bioenergy", "Biogas", and "Biofuels". Between 2010 and 2020, many research papers investigated, designed, and optimized co- and trigeneration systems in which bioenergy exploitation was discussed and inspected in over $45 \%$ of available publications. In particular, the research studies on this subject were carried out in order to simulate, optimize, and plan the operation of biomass-fired CHP or CCHP systems [43]. Research objectives concerning biomass utilization in energy systems may vary, as they rely heavily on factors such as location, considered configuration, and required application. Analyzing the employed methods and materials can only be managed if the research objectives of these studies are distinguished and classified. In accordance with the systematic literature search, the most common research objectives were energy and exergy analysis, thermo-economic optimization, and environmental evaluation. In this section, these three performance analyses are discussed thoroughly and studied with regard to biomass utilization.

\subsection{Energy and Exergy Analysis}

'Energy' is a term that is not only used in the scientific context, but it can also be heard in everyday conversation. The definition of this phenomenon may diverge in different sciences, but its true understanding has always been in representing power and effort. In engineering, this concept defines the ability or potential to do work. However, there 
is no single method of quantification of work since every process and unit has its own way and characteristics of performing it [44]. In this regard, one is required to study and understand the concept of energy utilization, production, and conversion within a system by performing energy analysis. The primary objectives of conducting such analysis are to acknowledge the energy production and utilization, determine the effectiveness of the system, and explore possible future developments [45].

Energy analysis can be defined as a means to assess energy utilization in an operation engaging in physical and chemical processes. It can be expressed as the quantification of energy flow into and out of a system [46]. On this account, this analysis cannot be considered a powerful option to identify and locate energy losses within a system. The separation of useful work from irreversibility and determining the associated energy-loss sources is a great approach toward evaluating an energy system from different aspects; hence, in search of defining the useful work in a process, the 'exergy' concept was described [47]. This phenomenon is based on the second law of thermodynamics and it is of the utmost importance in and of itself, which expresses the availability of energy (Figure 4) [48]. In generation plants, maximizing efficiency and minimizing energy destruction are the two primary necessities in which exergy evaluation plays a key role. Exergy analysis is a promising technique for determining exergy efficiency and quantifying energy dissipation so that possible options for enhancing efficiency can be identified [49]. Over the past few decades, this method of assessment has been studied comprehensively due to its numerous advantages over the energy balance approach (energy analysis). Interestingly, this analysis gained prominence for its performance evaluation, comparison, improvement, and optimization across different sectors. Some of the most significant benefits of exergy analysis can be summarized as follows [50]:

- Measuring exergy efficiency and providing information on the performance of the system concerning losses and imperfections in terms of overall and individual components in the system;

- Locating the sources of energy destruction and indicating the need for improvements;

- Ability to consider and link to other assessments, such as economic and environmental;

- It is a key parameter in developing optimization models.

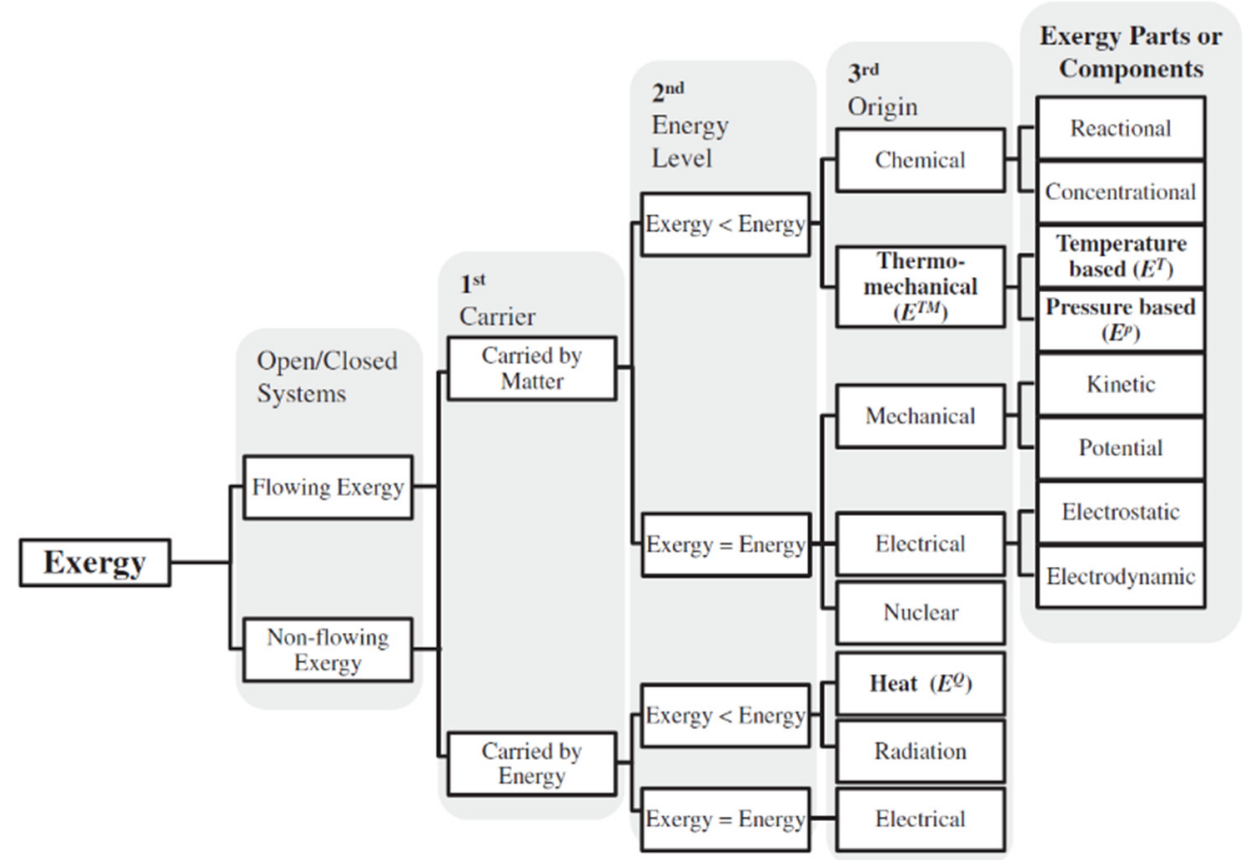

Figure 4. Classification exergy based on its source of generation [51]. 
In several studies, various configurations of bioenergy-integrated systems were modeled in accordance with the energy demands. Many researchers elaborated on the exergy analysis so as to evaluate the operation with respect to energy quality and outputs of their proposed systems [52-55]. Caliano et al. [52] conducted a research on a case study in Italy. They found that combination of thermal energy storage and cold thermal energy storage during the hot season is an economically valuable solution. Based on their findings in Reference [52], the optimal size of a biomass-fired CCHP system, including a CHP unit, a thermal energy storage, and an absorption chiller, was influenced by the value of feed-in premiums while the feed-in tariff variations had no effect on the optimal size of the system. The thermodynamic models of bioenergy-integrated plants are mainly based on mass, energy, and exergy balances. In several cases, the objective was clearly stated to meet the energy demands of a certain location or analyze the output capacity in the forms of electricity, heating, and cooling. In this context, there are multiple factors that can affect the performance of a system from different perspectives. Performing exergy analysis requires an understanding of the input and output units of the process for the reason that exergy calculations are actually based on these units with other influencing parameters, such as the temperature, pressure, and mass flow rate. With this regard, the mass balance for a steady-state system can be expressed as follows [30]:

$$
\begin{gathered}
\text { Input }+ \text { Generation }=\text { Output }+ \text { Consumption } \\
\sum_{i} \dot{m}_{j}=\sum_{o} \dot{m}_{j}
\end{gathered}
$$

where Generation and Consumption terms can be obtained from chemical stoichiometry and $\dot{m}_{j}$ represents the mass flow rate of input and output streams. Further, the energy balance can be expressed on a rate basis as follows:

$$
\begin{gathered}
\text { Input energy }=\text { Output energy }+ \text { Accumulation of energy in system } \\
\sum_{i} \dot{m}_{j}\left(\hat{U}_{j}+\frac{u_{j}^{2}}{2}+g z_{j}\right)+\dot{Q}=\sum_{o} \dot{m}_{j}\left(\hat{U}_{j}+\frac{u_{j}^{2}}{2}+g z_{j}\right)+\dot{W}+\dot{A}
\end{gathered}
$$

where $\hat{U}_{j}, \frac{u_{j}^{2}}{2}$, and $g z_{j}$ represent the specific values of internal energy, kinetic energy, and potential energy, respectively. The value of transferred heat into the system and the output work are indicated as $\dot{Q}$ and $\dot{W}$, respectively. An exergy analysis requires stating the exergy balance within a system. The balance requires detailed information regarding the structure. However, the exergy balance for the non-steady process in a system can be expressed as follows:

$$
\begin{gathered}
E x_{Q r}=Q_{r}\left(1-\frac{T_{o}}{T_{r}}\right) \\
E x_{W}=W
\end{gathered}
$$

The equation presents the net input rate of exergy (associated with the input fuel) in the first two terms. The following net input rate of thermal exergy and output work are calculated as follows:

Energy accumulation $=$ Exergy input - Exergy output - Exergy consumption

$$
\sum_{i} m_{i} e x_{i}-\sum_{o} m_{o} e x_{0}+\sum_{r} E x_{Q r}-E x_{W}-I=0
$$


Equation (7) is associated with the $Q_{r}$, which is the amount of input heat into the system across $r$ region on the system boundary. From Equations (8) and (9), the efficiency of the second law of thermodynamic can be expressed as follows:

$$
\eta_{e x}=\frac{\sum E x_{0}}{\sum E x_{i}}=\frac{\dot{W}_{n e t}}{\dot{m}_{f u e l} \Delta G_{T}^{0}}
$$

where it is the ratio of total output exergy to total input exergy. $\Delta G_{T}^{0}$ represents Gibbs energy of reaction, while $\dot{W}_{\text {net }}$ and $\dot{m}_{\text {fuel }}$ show the net output work and mass flow rate of the fuel, respectively. In order to calculate the irreversibility based on the second law of thermodynamic, it requires determining the total entropy change of the system.

$$
\begin{gathered}
d S_{\text {Total }}=\frac{d Q_{\text {actual }}}{T}+\frac{d W_{\text {lost }}}{T} \\
I=T_{0}\left[\frac{1}{\dot{m}} \frac{d S_{\text {net } / \text { real }}}{d t}\right]=T_{0} S_{\text {Gen }}
\end{gathered}
$$

where $d Q_{a c t u a l}$ is the actual heat received by the system. However, since the process is associated with irreversibility, the actual output work is always less than the one in the reversible process; therefore, the system produces additional entropy, which is expressed as $S_{G e n}$. This generation of entropy, which indicates energy destruction in a system, is considered at reference environment properties $T_{0}$.

The exergy analyses in biomass-fueled energy systems are based on the aforementioned concept, and the chemical exergy is of utmost importance in these systems. Chemical exergy is defined as the amount of work that can be obtained from the systems if the fuel is brought to an absolute equilibrium state with the environment [56]. In such configurations, the available exergy heavily relies on the physical and chemical components; therefore, properties such as the molar flow rate, specific chemical exergy, and enthalpy and entropy flow rates of the matter are the most significant parameters in the exergy assessment of the system. Equation (12) clearly presents the physical exergy, while Equations (13) and (14) provide the molar chemical exergy of component $i$ in the presence of a dry and humid reference environment, respectively [51].

$$
\begin{gathered}
E x_{p h}=H-H_{0}-T_{0}\left(S-S_{0}\right) \\
\bar{E} x_{i}^{c h}=\bar{R} T_{0} \ln \left(\frac{p_{0}}{p_{00}}\right) \\
\bar{E} x_{i}^{c h}=\bar{R} T_{0} \ln \left[x_{i}^{d r y}\left(1-\varphi \frac{p_{T_{0}}^{\text {sat }}}{p_{0}}\right)\right]
\end{gathered}
$$

where $\bar{R}$ is the universal gas constant $(8.3145 \mathrm{~kJ} / \mathrm{kmol} \mathrm{K}), \varphi$ is the relative humidity, $\bar{E}$ is the molar exergy $(\mathrm{kJ} / \mathrm{kmol})$ and $p$ is the pressure (bar). Similar to chemical exergy, there exist multiple approaches for formulating and calculating exergy efficiency in different configurations $[57,58]$. Within a certain process, the chemical exergy can be calculated with a single method but one can consider different techniques for exergy efficiency. It relies on the definition of exergy efficiency, which means that there exist different efficiency equations for various processes [59]. In this context, the exergy efficiencies are classified into two groups, including the following:

- Relative efficiency (overall exergy efficiency): The ratio of the total output exergy to the total input exergy;

- Consumed-produced efficiency (utilitarian exergy efficiency): The ratio of the exergy of the produced output to the exergy of the consumed input.

In relative efficiency, the total exergies of the input and output streams are of importance in order to determine the overall efficiency of the system or process. Since in 
many configurations a major part of the output is of use, authors tend to not consider differentiating exergy effectively. However, the exergy of input and output streams is not always equal to that of consumed and produced exergies. To this end, consumed-produced efficiency is expressed in five different definitions so as to calculate the efficiency from various perspectives. In several studies, both efficiencies were considered for better analysis and comparison of results [59,60]. For a better and precise understanding of exergy efficiency, Reference [51] investigated the available methods and drew a comparison with a focus on low-temperature processes.

\subsubsection{Biomass Influencing Factors in Energy and Exergy Analysis}

Biomass utilization in energy systems heavily relies on financial capability and implemented components. Since this type of RES is the most versatile of all, its conversion to useful energy can be considered in many ways. The combustion of biomass to produce flue gas (directly or indirectly) is one of the most common techniques. In exergy analysis, the combustion of solid biomass in gasifiers requires mass and energy balances, which are conducted throughout the whole gasification procedure across different interrelated processes, including drying (Equation (15)), pyrolysis, reduction, and combustion (Figure 5) [60]. Owing to the fact that flue gases are comprised of various properties, chemical reaction modeling is of importance as well. This allows performing the chemical equilibrium and further atomic balance of each species based on the obtained actual mass and gaseous volumetric fractions. Additionally, to quantify the input heat or transferred heat to the working fluid, the gasifier or boiler thermal efficiency is taken into account as well (Equation (16)). Besides the fuel mass flow rate and thermal efficiency of boiler, other factors, such as higher heating value $H H V_{b i o}$, the mass flow rate of working fluid in the boiler (water in this case), its heat capacity $C p_{\text {water, }}$ and its temperature difference in the boiler $\Delta T_{\text {water }}$, are also significant parameters that can impact the amount of provided heat by the biomass feedstock $[61,62]$.

$$
\begin{gathered}
\dot{m}_{\mathrm{H}_{2} \mathrm{O} \text { removed }}=\left(\psi_{\mathrm{H}_{2} \mathrm{O} \text { input }}-\frac{1-\psi_{\mathrm{H}_{2} \mathrm{O} \text { input }}}{1-\psi_{\mathrm{H}_{2} \mathrm{O} \text { output }}} \times \psi_{\mathrm{H}_{2} \mathrm{O} \text { output }}\right) \times \dot{m}_{\text {input wet bio }} \\
Q_{\text {bio }}=\eta_{\text {bioler }} \times \dot{m}_{\text {bio }} \times H H V_{\text {bio }}=\dot{m}_{\text {water }} \times C p_{\text {water }} \times \Delta T_{\text {water }}
\end{gathered}
$$

In exergy analysis, quantifying the input heat, efficiency of components, and exergy of the system can vary from one configuration to another due to the fact that biomass utilization can take various forms. For example, the combustion parameters of deployed engines in solid biomass-fueled plants can be assumed as one of the primary influences affecting energy outputs of a system $[63,64]$. Apart from the efficiencies of components, these parameters can be discussed in terms of the mass flow rate, the steam-to-biomass ratio (STBR), and heating values of different types of biomass resources $[65,66]$. In other cases, the exhaust temperature of the flue gas exiting out of the biomass boiler is of importance since it can affect the outputs of a system such as ORC (Figure 6) [67,68]. Obtaining this temperature requires an understanding of the chemical exergy of biomass resources and fuel composition. This factor may vary from one biomass type to another; therefore, it demands chemical reaction modeling $[69,70]$. Simulating the combustion of biomass in a gasifier reactor should be contemplated as realistically as possible. The input parameters of gasifiers can impact the operation and, consequently, the outputs significantly. There exist suggested models that consider different approaches for better simulation of the gasification process and energy balance in a gasifier. One of the methods is deploying a combustor along with the gasifier in order to achieve a more realistic energy balance and the production of alkali compounds [71,72]. 


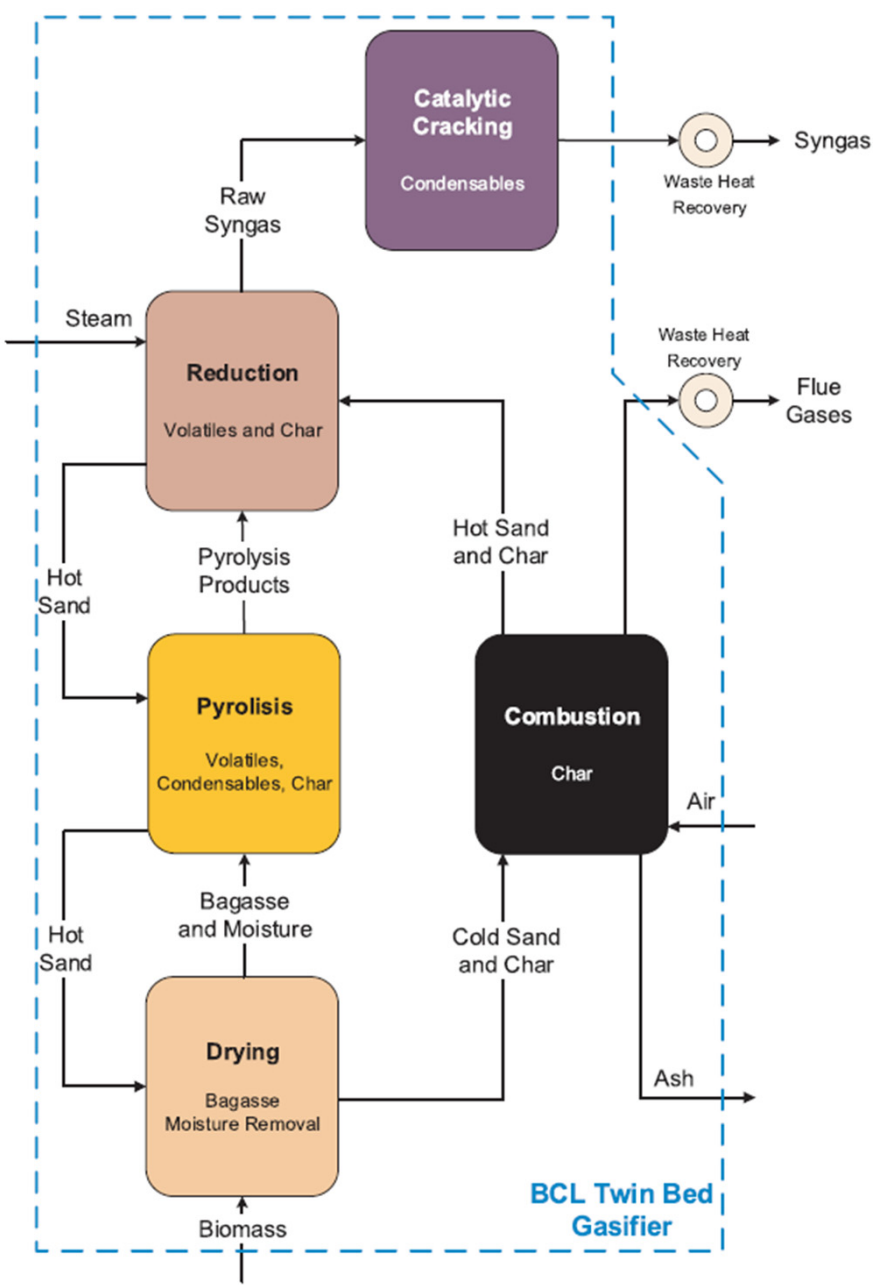

Figure 5. Modeling and simulation steps of the twin circulated bed BCL bagasse gasifier [60].

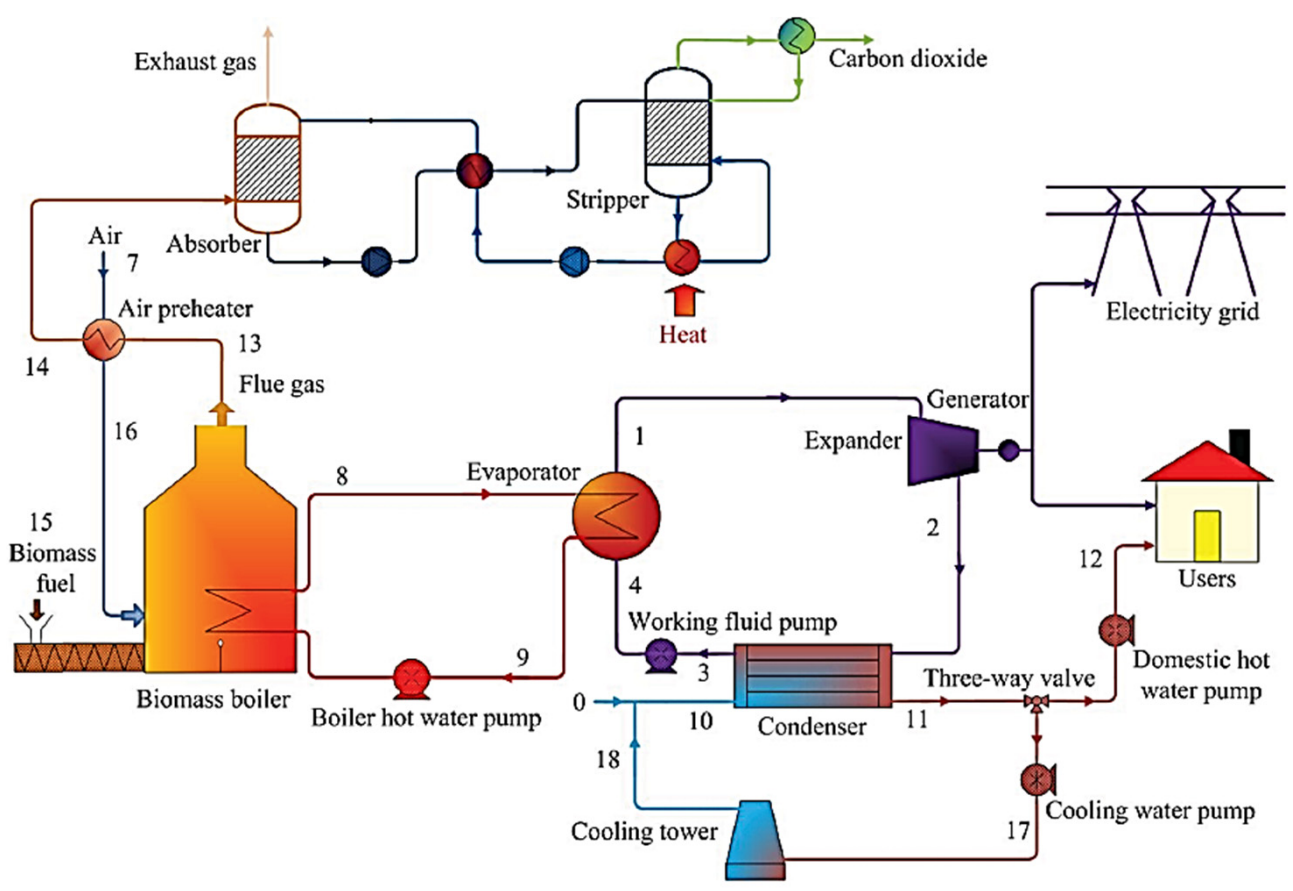

Figure 6. Schematic diagram of biomass-fired ORC-CHP system integrated with MEA-based $\mathrm{CO}_{2}$ capture [67]. 
The biomass conversion process can be designed and implemented with respect to the required output of the system. In several previous cases, such as those mentioned earlier, mostly power and heat were the needed outputs; as a result, the exergy assessment was modeled and formulated based on power and heat production. However, this is not the case for all available configurations. Certain systems demand other forms of products, such as syngas, hydrogen, or even biofuels, for various applications [73-75]. To this end, implementing and analyzing these systems in the same way as previous cases does not guarantee feasible exergy evaluation and maximum production of other products. Understanding the gasification reactions, dividing the processes, implementing exergy balance, and formulating a process performance index (PI) in accordance with the required demand can be a promising approach for obtaining maximum production and efficiency in a system. Regardless of the biomass properties or combustion parameters, there are other disturbances within a system that can affect the operation and outputs. These disturbances should be taken into account when designing and simulating the model in order to guarantee the accuracy of the results and performance. Such disorders can take place due to component malfunctions or variations of parameters. For example, changes in the boiler load can impact district heating $(\mathrm{DH})$ generation and the supply temperature $[76,77]$. In exergy analysis, the constraints and disturbances should be accounted for so as to implement a realistic system with promising results.

\subsection{Thermo-Economic Optimization}

The operation of every energy system is associated with losses and imperfections. To achieve optimum performance, considering the objective functions, energy dissipation should be taken into account, and optimization of the operation should be conducted in terms of economic, thermodynamic, and/or environmental aspects. Following Balaji's work [78], mathematical optimization techniques can be classified into two primary groups, namely, the calculus method and the search method (Figure 7) [78-80]. The calculus method, or famously known as the gradient method, utilizes first- and/or second-order derivatives to determine the extremum, whereas the search method does not require a gradient and progressively follows a random or systematic pattern (sequence) in order to improve the objective function $[81,82]$. Owing to the availability of the derivative information, the calculus method benefits from faster convergence compared to the search method [83]; however, it can only be employed when the constraints are differentiable and equalities, as well [80]. Over the past decades, designing and implementing complex energy systems created complex engineering problems, which forced engineers to develop new optimization techniques so as to encounter multiple issues with a single optimization model. Although the classic methods are efficient at solving a particular problem at the local level, their performance can suffer when subjected to a multi-objective system or considered at the global level. These methods tend to converge to an optimal solution based on the initial point, and their implementation on parallel machines is not feasible [84]. To this end, several other new approaches were proposed and conducted for different applications, the majority of which were mainly based on the search method and evolutionary principles. Optimizing a system requires analysis of the operation in order to realize the associated drawbacks and the need for optimization. In the previous section, it was presented that exergy analysis is a promising approach for evaluating the operation of an energy conversion system, which correspondingly indicates the necessity for optimization. Figure 8 shows the required steps for exergy analysis and realizing the need for optimization, while Figure 9 depicts the optimization flow chart. 


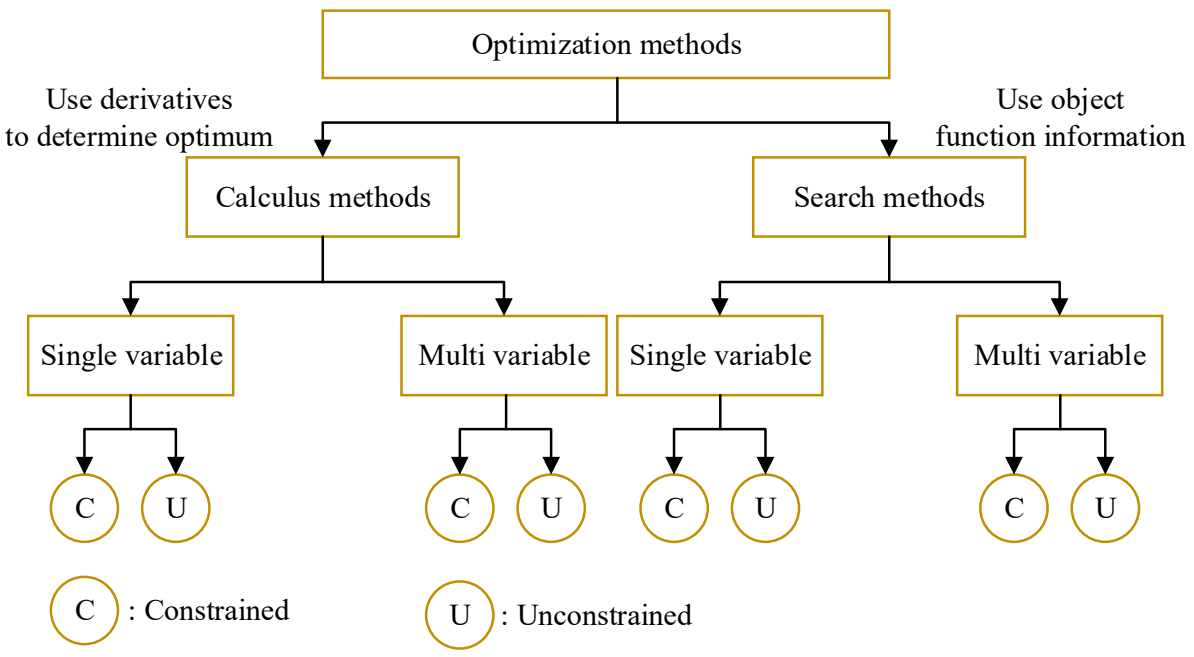

Figure 7. Classification of optimization problems.

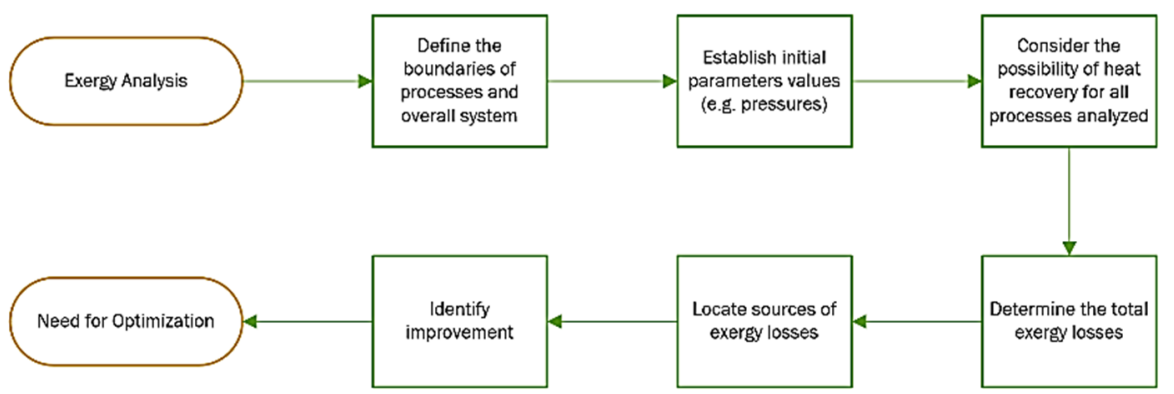

Figure 8. Block diagram of the required steps for conducting exergy analysis.

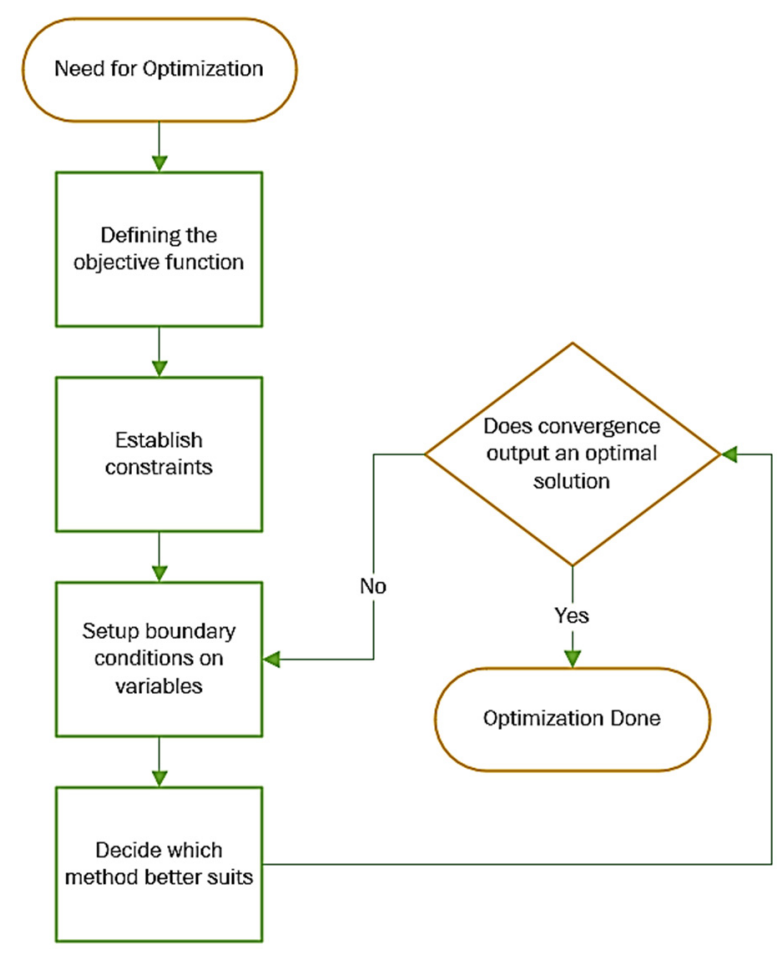

Figure 9. Flow chart of an optimization model. 


\subsubsection{Biomass Influencing Factors in Thermo-Economic Analysis}

In bioenergy-integrated systems, optimization can be performed concerning energy conversion, biomass consumption, environmental impacts, and financial benefits. There exist various influencing factors that can affect these aspects from different perspectives; therefore, their variations should be accounted for. In the vast majority of CHP or CCHP systems, thermodynamic and economic analyses are the most common approaches toward evaluating the operation and eventually optimizing it. Thermodynamic evaluation combines the first and second laws of thermodynamics in order to provide a better understanding of the system's overall performance and allows to determine the sources of energy dissipation due to the irreversibility involving each process [85]. However, this assessment does not necessarily guarantee the financial feasibility of a system and it cannot provide any means on how to allocate costs between the components and their products. To this end, the thermodynamic analysis was extended to include several other assessments, such as thermo-economic, exergo-economic, pinch analysis, and exergy analysis [86]. Numerous studies conducted thermo-economic assessments so as to tie the thermodynamic analysis to economic aspects of a system, aiming at the detailed evaluation of the cost of exergy [87]. In several cases, these assessments were carried out for developed models of CHP and CCHP configurations [88-90], while in other studies, they were employed in high-energy consumption processes, such as in wastewater treatment plants (WWTP) [91]. The analyses may vary from one study to another. For instance, in a WWTP anaerobic digestion and gasification process, evaluation is of importance (Figure 10) [91,92], whereas boiler operation is more critical in biomass-integrated ORC systems (Figure 11) [61,93]. In this regard, there exist a number of technologies and measures that can be implemented in accordance with the requirements [94]. Commonly, researchers tend to develop a thermochemical equilibrium model when the output product is in a gaseous or liquid form in order to determine the property of the product(s), particularly the energy content $[95,96]$. On the other hand, mass and energy balances are mostly employed for the boiler's operation in biomass combustion systems when the output thermal energy is only of importance. In the vast majority of biomass-fueled systems, at first, the exergy analysis is conducted in order to evaluate the technical operation and determine the thermodynamic objective functions for optimization purposes. Then, the economic analysis is formulated and the economic objective functions are realized. Biomass influencing factors in terms of thermodynamic performance were discussed in Section 2.1.1. In this regard, this section investigates the economic analysis, its relation to exergy assessment and indicates the basis of economic evaluation in energy systems, such as biomass-fueled IESs.

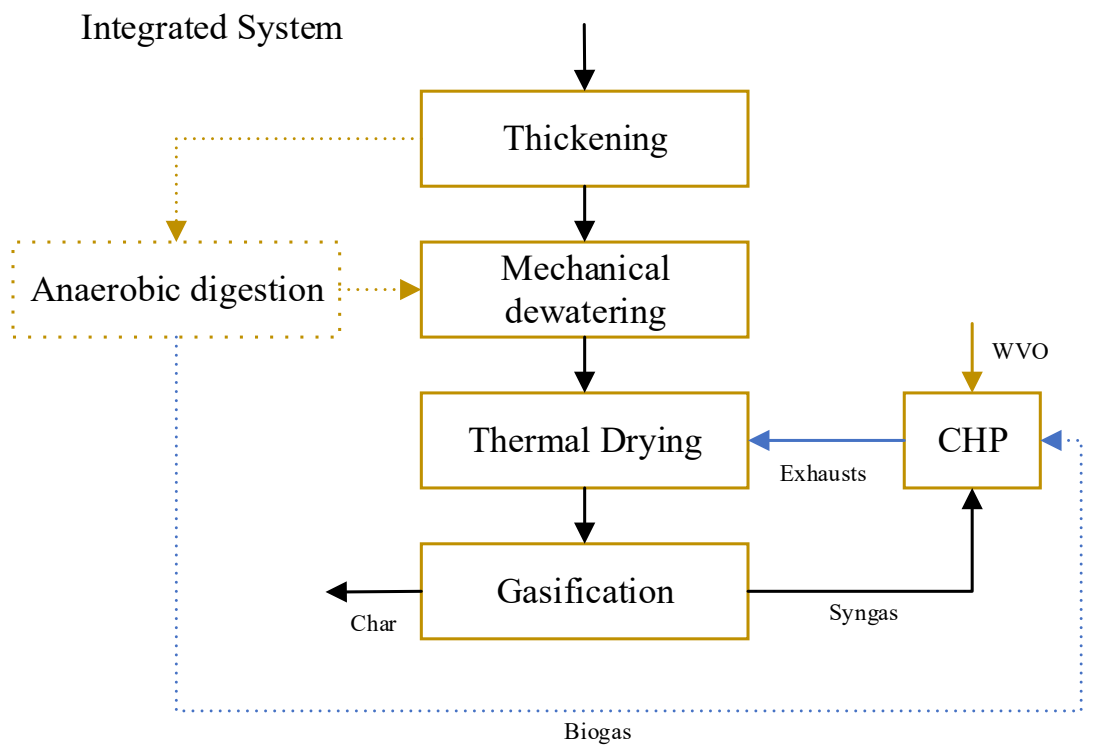

Figure 10. Block diagram of a bioenergy system in WWTP facility (WVO = waste vegetable oil). 


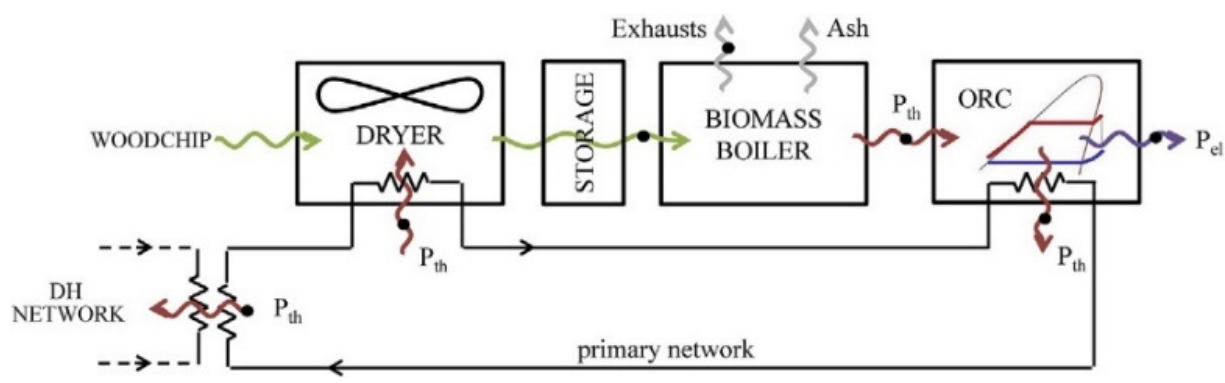

Figure 11. Structure of a biomass-fueled ORC system [93].

The development of any energy-conversion system is associated with boundary conditions due to the availability of resources, financial capability, governmental regulations, and environmental protection. For implementing an optimization model, these boundaries should be taken into consideration so as to integrate an efficient system with minimum cost [97]. As mentioned before, thermo-economic optimization not only addresses thermodynamic performance, but also includes the economic aspects of a system in order to tie both cost and exergy concepts with the intention of developing an efficient system that is financially viable as well. In such assessment, the energy system can be inspected based on its financial profitability and efficiency, with respect to fuel consumption. Considering the economic point of view, the financial factors of an energy system can fall into three main categories, including fuel cost (resources, part-load operation), operation and maintenance (labor, equipment maintenance, start-up/shut-down period), and capital cost (total investment, unit cost). The costs associated with producing a good in an energy system are of two kinds, namely the following [98]:

- $\quad$ Average cost: Per unit cost of production (not predictive).

- Marginal cost: Changes in the total production cost by producing an additional unit (predictive).

In biomass-integrated systems, the generation of power and any other forms of energy rely heavily on the required demand. Therefore, the rate of generation might vary over time, which results in variable fuel consumption and operating hours. With this regard, the cost formulation should have the capability to account for the variations and predict the overall and specific costs in the case of any modification. This can be taken into consideration by conducting thermo-economic optimization, which is mainly based on the marginal cost concept [99]. In energy generation plants, the exergy of fuel should be greater than or equal to that of output products overall and any unit of the system [100]. This concept allows the determination of the unit cost of a single product; additional criteria are required for linking the unit cost of different products in multi-energy systems [101]. A thermo-economic analysis is mainly conducted to determine the cost of each produced good, such as power, heat, cooling, etc., understand the cost flow within the system, express the price of components as a function of the thermodynamic decision variable, and improve the efficiency of generation in accordance with the financial and environmental benefits [102]. Yasar Demirel, in his review article [86], classified the available thermoeconomic optimization methods (based on their objectives) into two groups including the following:

- Cost accounting and optimization method (such as considering the total specific cost of AD-CHP plant in Reference [103]).

- Overall cost minimization method (such as minimizing ethanol production cost in the CCHP plant in Reference [104]).

Commonly, the revenue in energy systems is calculated by subtracting expenses from the sales of goods and services. The cost-minimization approach involves only the marginal cost in order to concentrate its resources, where the excess of the marginal revenue over marginal cost is maximal. On the other hand, the cost accounting method is based on the cost allocation concept, and it provides detailed cost information comprising resources, 
operation, maintenance, and capital accumulation. In order to link the overall efficiency and the cost of output products of a structure with the efficiency and irreversibility of each individual unit within the structure, general formulas are required to identify the process of cost formation. This approach provides management with critical planning and controlling data concerning energy consumption, generation efficiency, energy losses, and costs (overall and each unit of the system) for decision-making purposes. In the same way as exergy and energy balances, the thermo-economic cost performance of each unit ' $n$ ' within a system should be balanced in terms of the cost rate of output work $\dot{C}_{w, n}$ and input heat $\dot{C}_{Q, n}$. The thermo-economic cost balance and exergy costing equations can be expressed as follows:

$$
\begin{gathered}
S S_{C H P}=E P+\left(\frac{\eta_{0}}{\eta_{e}}-1\right)\left(\frac{G P}{\eta_{b}}\right)-\frac{G P}{\eta_{e}} \\
A^{\prime} \times \Pi+Z=0 \\
\Pi=B_{D}^{*} \times c^{*}=c_{D}^{*} \times B^{*} \\
\sum_{o} \dot{C}_{o, n}+\dot{C}_{w, n}=\sum_{i} \dot{C}_{i, n}+\dot{C}_{Q, n}+\dot{Z}_{n} \\
\dot{Z}_{n}=\frac{(C I \times C R F) \times(1+\xi)}{O P H} \\
C R F=\frac{i(1+i)^{p}}{(1+i)^{p}-1} \\
\dot{C}_{o}=c_{o} \dot{E} x_{o} \\
\dot{C}_{i}=c_{i} \dot{E} x_{i} \\
\dot{C}_{w}=c_{w} \dot{W} \\
\dot{C_{Q}}=c_{Q} \dot{Q}
\end{gathered}
$$

In any IES, discussion of its economics, including the relative price of electricity and fuel, is of utmost importance. This quantity is expressed via a metric known as spark spread, which is defined as the net profit from selling one unit of electricity and heat after purchasing the required fuel [105]. Equation (17) presents the spark spread of a CHP system in which EP and GP are the electricity and gas price, respectively. The price of heat is defined as the cost of heat produced in a boiler, where $\eta_{e}, \eta_{o}$, and $\eta_{b}$ are the CHP's electrical efficiency, overall efficiency, and boiler's efficiency, in that respective order. Equation (18) presents the general form of the thermo-economic cost balance. The variable $A^{\prime}$ is the cost matrix of a system, $\Pi$ is the thermo-economic cost vector, and $Z$ is the vector containing the levelized cost of maintenance, operation, and investment. Further, Equation (20) indicates the thermo-economic cost balance for a $n$th component, receiving heat as input and generating work or power as the output. Equation (21) depicts the cost rate of $Z$, which is based on capital investment (CI), the capital recovery factor (CRF), operating hours $(\mathrm{OPH})$, and the maintenance cost rate $(\xi)$. The $\mathrm{CRF}$ can be calculated based on the interest rate $(i)$ and service life $(p)$ of a system (Equation (22)).

In generation systems, it is of utmost importance to determine a criterion (objective function) for optimization purposes. There exist several objective functions depending on the requirements and boundary conditions, such as efficiency enhancement, power output maximization, minimization of biomass consumption, maximization of net present value $(\mathrm{NPV})$, and minimization of the levelized cost of any form of required energy (usually electricity (LCOE)) [106]. Commonly, these objective functions require a reference criterion for comparing the effectiveness of the suggested model with conventional methods. This comparison can be in terms of satisfying energy demands of a certain location [61], or it can be based on output generation capacities [107]. However, it should be noticed that 
not all objective functions result in thermo-economic optimization. This is due to the fact that the thermodynamic objective function, such as improved thermal exergy efficiency or maximum power output, does not guarantee financial feasibility and might increase the overall cost of the system [108]. It is worth mentioning that the selection of objective function relies heavily on the overall objectives and design requirements. In this context, exergy and economic analyses are required to be performed so as to determine the objective functions appropriately. Similar to the exergy analysis, there are also financial factors and indices that can affect the economic evaluation of a system, including but not limited to the operating cost, fuel cost, unit cost of energy, construction time, commission time, etc. With this regard, the economic assessment should be performed as discussed so as to tie both the thermodynamic and economic principles together.

\subsection{Environment Assessment}

Environmental concerns and issues have been continuously growing across local, regional, and global sectors. Such problems are either derived from chronic effects, which can impact human health, or result from the accidental discharge of hazardous substances. The vast majority of environmental concerns in the energy sector are raised as a direct consequence of energy conversion, generation, and transportation. The impacts can appear in many forms, such as solid waste disposal, air pollutants, and water pollution [109]. The low cost of fossil fuels has transformed this harmful enemy of the environment into the primary and most significant source of energy in various sectors [110]. The catastrophic effects of fossil fuels on climate change have reached a point where societies' transitions to a net-zero carbon state is no longer effective, and active $\mathrm{CO}_{2}$ removal should be implemented in order to limit atmospheric warming. To replace fossil energy with sustainable sources and contribute to the carbon sequestration concept, biomass utilization is quickly expanding and gaining prominence. Mainly, biomass can be harvested from various planet materials, such as forests, wastes, and landfills. Although these resources are considered sustainable, their excessive consumption can lead to ecological imbalance, which results in serious environmental impacts. The scale at which this RES is being used is of importance in every sector due to the fact that it can be as harmful as fossil fuels if the environmental reliability conditions are not met [111]. Concerning carbon sequestration, several approaches have been suggested over the past years to incorporate biomass resources for the active removal, capturing, and sequestrating of $\mathrm{CO}_{2}$ from the atmosphere. Apart from well-established techniques, such as carbon farming, afforestation, and reforestation, the practical viability of bioenergy carbon capture systems and biochar has been investigated in recent years [112]. However, developments in the carbon capture field have faced controversial views in terms of economic viability and biodiversity conservation. While many experts believe that bio-sequestration is relatively cheaper and more effective than other carbon mitigation alternatives, others question the practical viability of these techniques due to their major impacts on water and land resources. In addition, mechanical sequestration, such as direct air capture, is still not practically feasible since such techniques are very energy intensive. Utilizing biomass feedstock to simply replace centralized carbon resources is more cost-effective than utilizing it for direct carbon capture [113]. In this context, biomass reliability in terms of environmental aspects is a critical subject that should be taken into consideration.

\subsubsection{Biomass Influencing Factors in Environmental Analysis}

The statement that indicates "Anything that reduces the consumption of fossil fuels will therefore benefit the environment" is far from the reality. In fact, every new technology introduces both benefits and costs for which it is society that decides the true value [114]. As much as biomass utilization can be beneficial, its consumption is associated with environmental impacts. To understand the reliability of this resource, it is wise to evaluate its influence on the surrounding environment. Evidently, the environmental impacts of biomass rely heavily on the production to demand ratio [115]. The level at which biomass 
consumption can affect the environment is classified into two groups, including land and other resources, and the surrounding environment. Since solid biomass is mostly derived from agricultural and forest lands, its utilization can impact these resources significantly. In order to realize its level of influence on lands and other resources, it is of utmost importance to answer questions concerning the demand for biomass, the efficiency of land use and the type of land to be utilized [116]. Biomass crops grown on degraded lands are important sources of bioenergy production due to the fact that this type of land is of no use to agriculture or forestry, and they do not result in deforestation and negative impacts [117]. However, such lands are not always cost-effective and suitable options for bioenergy development since they may require fertilization and irrigation processes [111]. The increasing demand for solid biomass has less influence on agricultural lands, except in the case of energy crop development in European countries. The vast majority of the supply is satisfied by extracting biomass resources from the forest and degraded lands; therefore, the increasing demand is causing excessive extraction from existing forest resources, which may result in serious consequences [116]. With this regard, the impact of solid biomass on lands and other resources should be taken into account and government mandates must be imposed to improve the reliability and sustainability of this source of energy.

The influence of biomass consumption on the surrounding environment is another important factor that should be investigated precisely. The impacts are mainly derived from the generation of energy, in any form, and they are capable of affecting the climate, water resources, soil resources, and biodiversity. The quantitative analysis of biomass impacts on the environment is a complicated approach. Biomass consumption is associated with characteristics such as emissions, waste disposal, and ecological damage that must be quantified. To this end, environmental analyses that determine the reliability of biomass utilization in an energy system and provide helpful information concerning possible improvements within a structure are performed so as to develop environmentally friendly biomass-fueled energy systems [118]. In terms of climate impacts, biomass combustion is mainly accompanied by $\mathrm{CO}_{2}$ emissions, such as the case with fossil fuels. There is no doubt that the level of concentration of harmful gases, such as $\mathrm{NO}_{\mathrm{x}}$, is lower than fossil fuels; however, solid biomass emits more carbon dioxide per unit of energy produced. This can be due to the fact that no emission standards or precise monitoring of biomass utilization are available at this moment. While environmental agencies mandate fossil fuel-based generation plants to implement emission-reduction technologies, biomass-fueled facilities are not required to do so, which can give rise to serious climate impacts at local and global geographical scales in the near future [119]. Biomass impacts on water resources originated from high-demand water use for growing energy crops. This impact is largely depended on climate conditions and the availability of water resources in a country. Expectedly, biomass crops that are planted on degraded lands for energy production require higher water demands compared to agricultural ones. In some countries, such an approach can have positive impacts on both land and water resources; however, if the country is struggling with water shortages, this can be reversed [120]. Additional effects of biomass on soil resources and biodiversity rely heavily on the utilized crops, their level of production, and the method of harvest. There is no doubt that biomass can have significant benefits on all mentioned resources and aspects. This type of energy source can lower emissions by $50-60 \%$ on average, save water, improve soil conditions on degraded lands, and increase the level of biodiversity. However, the sustainability level should be maintained and environmental analyses should be performed in order to avoid any ecological imbalance and further damages [121].

Over the past few decades, an environmental analysis has been developed and conducted to identify, analyze, and evaluate the effects of energy production on the environment. This type of assessment can be undertaken for biomass-integrated energy systems so as to detect the potential risk to human health and the surrounding environment. One of the most common, well-studied, and internationally recognized techniques is life-cycle assessment (LCA). This method determines the environmental impacts of an energy sys- 
tem throughout the entire life cycle of its products. Such analysis is implemented for product-oriented systems in order to evaluate the environmental effects and emission indicators that a single product or process can cause (Figure 12) [122]. In recent times, this analysis has gained prominence for its capability for quantifying emissions and wastes over the complete supply chain of products. LCA model development should follow the principles and requirements within ISO 14040 and ISO 14044 [123,124], and it also depends considerably on the life cycle inventory (LCI) and impact categories being investigated. There exist various impact categories and their associated impact indicators, which are capable of grouping different forms of emissions into one environmental effect at local, regional, and global levels [125]. Precise and detailed categories and their associated impact indicators can be found in Reference [126]. In the LCA model, it requires quantifying the inputs and outputs for a product throughout its life cycle [127]. This can be done by creating a life cycle impact (LCI) parameter in which the flows into and out of a process are quantified and compiled. Frequently, LCI is considered for each process from the first steps of biomass production to the last steps of energy generation and use [128]. Despite the thoroughness of the LCA technique, this approach has been criticized due to its complexity and availability of data [129]. To this end, several other methods, such as direct emissions, were developed to analyze energy systems in terms of environmental aspects (Figure 13) [130]. Most of these techniques only consider the emissions of the plant itself as the responsible factor for environmental impacts. Any ecological damages involving the prerequisite processes are not taken into account [131]. In this context, there is no doubt that these methods are associated with marginal errors and lack of precision; however, implementing these assessments is still considered as viable and important as the LCA method. Most of these analyses are employed to draw comparisons between multiple renewable-based energy systems, such as the biogas-fueled CHP and CCHP systems in Reference [132], the biomass-based trigeneration mode and stand-alone electricity mode in Reference [133], or simply the biomass-based ORC and fossil-fueled energy systems in Reference [131]. In these evaluations, it is the comparison's results that indicate the effectiveness and feasibility of the proposed structure.

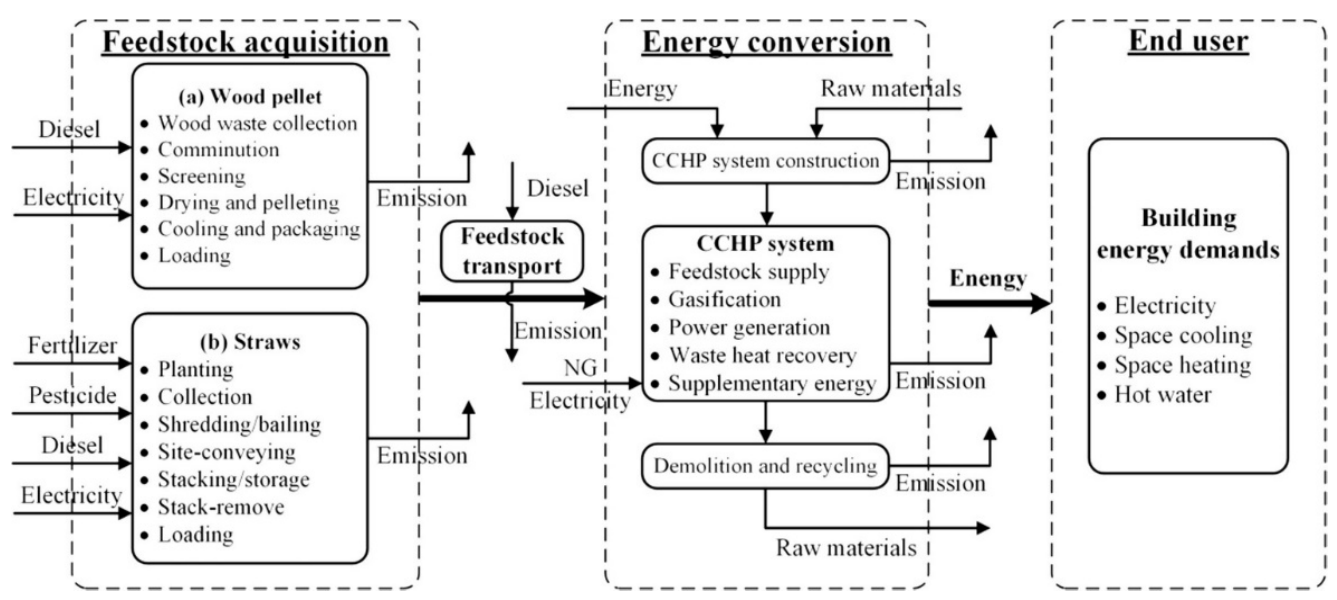

Figure 12. LCA boundary diagram of the biomass gasification-integrated CCHP system [89].

Environmental analyses for biomass-integrated configurations can be considered based on various influencing factors, such as emissions, waste disposal, and sustainability. The level of $\mathrm{CO}_{2}$ emissions is the only figure that the majority of studies are interested in. This emission level can be expressed in terms of emissions rate Equation (27) [132,134,135], reduction ratio Equation (28) [131,133,136], or avoidance ratio Equation (29) [137].

$$
\varepsilon_{\text {em }, \mathrm{CHP}}=\frac{\sum_{i} \dot{m}_{\mathrm{CO}_{2}}}{\left(\dot{W}_{\text {net }}+\dot{Q}_{\text {heating }}+\dot{R}_{\text {cooling }}\right)}
$$




$$
\begin{gathered}
E R_{\mathrm{CO}_{2}, \mathrm{CCHP}}=\frac{\left(m_{\mathrm{CO}_{2}}\right)_{S P}-\left(m_{\mathrm{CO}_{2}}\right)_{\mathrm{CCHP}}}{\left(m_{\mathrm{CO}_{2}}\right)_{S P}}= \\
=1-\frac{\left(\mu_{\mathrm{CO}_{2}}^{\mathrm{F}}\right)_{\mathrm{CCHP}} F_{\mathrm{CCH} P}}{\left(\mu_{\mathrm{CO}_{2}}^{\mathrm{W}}\right)_{S P} W_{\mathrm{CCHP}}+\left(\mu_{\mathrm{CO}}^{\mathrm{Q}}\right)_{S P} Q_{\mathrm{CC} H P}+\left(\mu_{\mathrm{CO}}^{\mathrm{R}}\right)_{S P} R_{\mathrm{CCHP}}} \\
A V \mathrm{CO}_{2}=f_{E}+\left(\frac{V_{\mathrm{H}}}{E}\right) \cdot\left(\frac{f_{\mathrm{NG}}}{\eta_{\text {refHng }}}\right)+\left(\frac{V_{G}}{E}\right) \cdot\left(\frac{f_{E}}{\mathrm{CSP}_{\text {refCom }}}\right)
\end{gathered}
$$

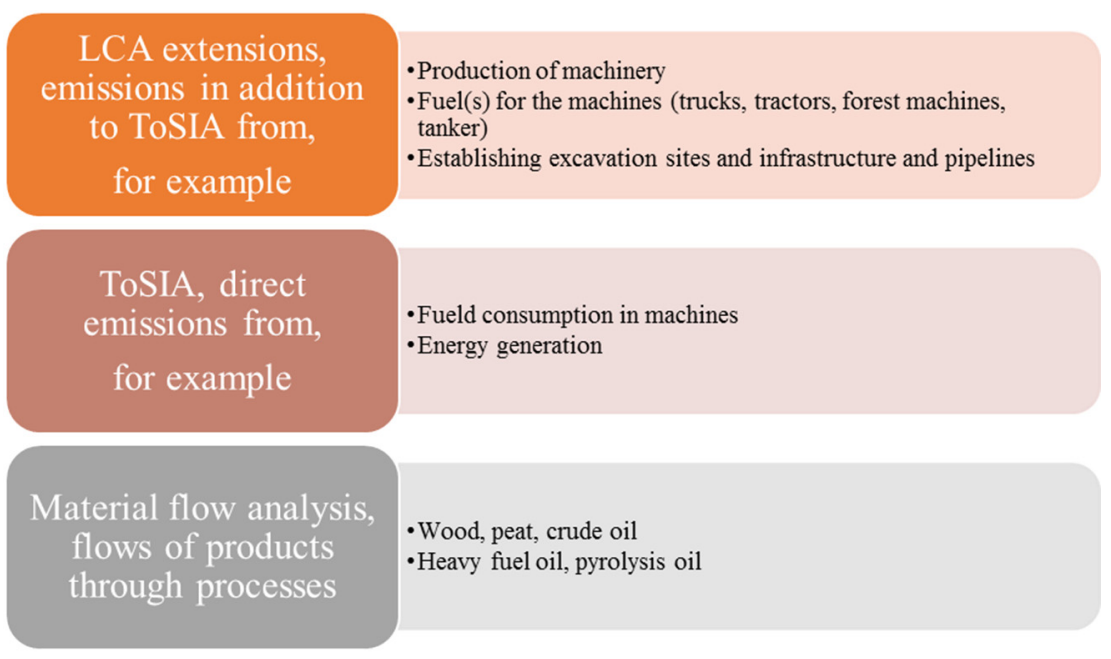

Figure 13. The principle difference between the diverse methodologies of environmental analyses.

Equations (27) and (28) are expressed for a CCHP system. Equation (27) defines the amount of emitted $\mathrm{CO}_{2}$, for which $\dot{m}_{\mathrm{CO}_{2}}$ is the mass flow rate of the $\mathrm{CO}_{2}$ content of input biomass, and $\dot{W}_{\text {net }}, \dot{Q}_{\text {heating, }}$ and $\dot{R}_{\text {cooling }}$ present the output work, heat, and cooling of a CCHP plant, respectively. In Equation (28), the emission reduction (ER) ratio is presented as the relative change ratio of $\mathrm{CO}_{2}$ emissions of separate production (SP) and CCHP. The mass of emitted $\mathrm{CO}_{2}$ after input biomass combustion is given as $m_{\mathrm{CO}_{2}}$ for both SP and $\mathrm{CCHP}$ configurations. The extended version of this equation defines $\mu_{\mathrm{CO}_{2}}^{\mathrm{W}}, \mu_{\mathrm{CO}_{2}}^{Q}$, and $\mu_{\mathrm{CO}_{2}}^{R}$ as "the energy-output related emission factors" for the separate production of electricity, heating, and cooling, respectively, while $\mu_{\mathrm{CO}_{2}}^{F}$ is indicated as "the specific input fuel to the trigeneration system" [136]. Equation (29), on the other hand, is based on the assumption that biomass is considered neutral in $\mathrm{CO}_{2}$ emissions. In this equation, $f_{E}$ and $f_{N G}$ are the average emission factors for electricity and natural gas, $\eta_{\text {refHng }}$ is the efficiency for natural gas heating, and $C S P F_{r e f C o m}$ is the performance factor for a conventional cooling compressor. Since there is no specific formula on how and in what capacity biomass can avoid $\mathrm{CO}_{2}$ emissions [137], such self-defined equations can be formulated to indicate how much biomass combustion can save emissions compared to conventional systems.

\section{Conclusions and Future Perspective}

Over the past decades, the development of IES configurations has seen a considerable increase, and the economic and environmental benefits of them have been realized. The minimization of PEC, improvement of generation efficiency, reduction in environmental consequences, and provision of operational flexibility for greater penetration of renewable energy sources are the primary advantages of CHP and CCHP systems. Undoubtedly, the integration of renewables into such systems adds additional benefits and contributes significantly to the energy transition goal. The possibility of biomass integration into cogeneration and trigeneration systems was precisely discussed in this study. In general, biomass resources are utilized in IES via combustion, gasification, and ignition. There exist various conversion technologies as well as the possibility of their integration that can provide certain advantages for specific types of feedstocks. The modeling and operation 
of each type differ from one another, and consequently, the analysis and evaluations of the systems. In this context, three primary system analyses, including energy and exergy analysis, thermo-economic optimization, and environmental assessment for biofuel energy systems were realized and investigated thoroughly. The principles of each evaluation were completely discussed, and the influencing factors of biomass utilization were pointed out. Seminal contributions elaborated on each performance analysis; it was found that the molar structure of feedstock, associated costs with the biomass-to-bioenergy process, and sustainability of biomass were the primary influencing factors that could significantly affect the results of each assessment. The low energy density of such fuel poses financial disadvantages, which can result in lack of development. The cost of transportation in bioenergy systems is often a primary concern since the supply is usually far from the generation system, and due to the low energy density of such fuel, transportation costs can affect the feasibility of the entire system. Moreover, the cost competitiveness between the fossil fuels and the bio-based fuels still remains a primary concern for the investors since there are projects similar to GoBiGas Göteborg that are failing due to the lower cost of natural gas. Thermo-economic analysis is required to conduct a comparative analysis between different bioenergy systems to present the financial feasibility of each method of utilization. For instance, gasification systems are more advantageous over direct combustion for CHP generation. This is due to the fact that gasification systems can take advantage of a higher power conversion efficiency, while on the other hand, direct combustion can be utilized for locations with high thermal energy demand.

Predicting the future might not be wise, but with a clear understanding of the negative impacts of conventional energy generation on the planet and all living species on it, there is no doubt that $\mathrm{CHP}$ will be featured in all future energy scenarios. The depletion of fossil fuels and growing concerns over primary energy consumption would ensure the long-run existence of this type of energy generation, where heat, as well as power, is demanded. The possible integration of hybrid systems is also important to energy transition goals. In future scenarios, it will be likely to see the large integration of CHP units for satisfying the thermal demand. In such scenarios, the interconnection of multiple CHP units allows satisfaction of thermal energy, while the excess electricity is either utilized in further processes or exported to the grid, providing higher revenue for the system. Similarly, utilization of renewable energy sources (RES) such as biomass in CHP systems or developing hybrid-CHP configurations will be the mainstream topic that provides the largest future opportunities. Looking into the future, the international strategies imposing low-carbon emission may force the attention toward technologies cooperating with this condition; bioenergy resources are undoubtedly the first option to investigate. To this day, traditional combustion of biomass for heat generation still holds over $80 \%$ of the utilization share. However, the current trends illustrate the fact that the increasing need for other forms of energy, such as power, biomethane, biodiesel, and ethanol, is shifting the share toward other utilization methods. Amongst these techniques, gasification is a promising approach that is gaining interest in power and biogas generation. In the near future, it is expected to witness the highest contribution in the bioenergy industry related to gasification systems. The vast majority of current deployments present higher financial gains in comparison to conventional combustion systems. Additionally, transition in the transportation sector is demanding fossil fuel replacement with electricity and green fuels. Given the current trend for electric vehicle production and replacement, the set goals for 2030 and 2050 cannot be met; hence, there is a need to search for other replacements, such as biodiesel and synthetic fuels. Biomass resources can be utilized for the production of such fuels; in fact, biomass is the only cost-effective source in the production of synthetic fuels in comparison to carbon-capture systems. In this regard, pyrolysis systems, anaerobic digestion, and gasification systems could be developed for this application. However, each may illustrate certain advantages over the other in terms of technical and financial performance, which requires further research. 
The lack of government incentives and regulations, flexibility in power systems, and economic attractiveness are the primary challenges that must be addressed in the near future. The influencing factors for facing these challenges should be investigated in different sectors to solve the associated problems with the market mechanism. Cost competitiveness and regulatory frameworks are the potential topics that should be discussed and evaluated at the regional level. Further, flexibility improvement is one of the most important subjects that should be emphasized in developed countries. The lack of transmission structures to accommodate higher variable renewable generation results in significant curtailment and hesitation for further development. The establishment of feed-in tariffs and the possible connection of distributed generations to the main grid introduce a considerable growth in decentralized generation. However, this should be taken further for biomass utilization, as economic feasibility is an important uncertainty in such generation. The need to go beyond woody biomass resources is a necessity for bioenergy development. Biowastes are great sources of energy that require both research and financial attentions to be implemented in future energy systems, as conventional woody biomass feedstocks are facing supply and demand mismatches, particularly in the European Union.

Author Contributions: All authors have contributed to writing and editing this article. Writing original draft preparation, M.A.B. and K.M.; funding acquisition, Z.A.-M. and S.R.; supervision, K.M.; writing-review and editing, S.R., Z.A.-M., A.B.P. and S.M.A. All authors have read and agreed to the published version of the manuscript.

Funding: The financial support is obtained from Universiti Teknologi Malaysia (grant numbers 4B482, 05G88, and 02M18).

Institutional Review Board Statement: Not applicable.

Informed Consent Statement: Not applicable.

Data Availability Statement: Not applicable.

Acknowledgments: The authors gratefully acknowledge the financial support from Universiti Teknologi Malaysia (grant numbers 4B482, 05G88 and 02M18). Authors also wish to thank the University of Nottingham Malaysia.

Conflicts of Interest: The authors declare no conflict of interest.

\section{Abbreviations}

$\begin{array}{ll}\text { RES } & \text { Renewable Energy Source } \\ \text { GHG } & \text { Greenhouse Gases } \\ \text { CHP } & \text { Combined Heat and Power } \\ \text { CCL } & \text { Climate Change Levy } \\ \text { CCHP } & \text { Combined Cooling Heat and Power } \\ \text { ppm } & \text { Parts Per Million } \\ \text { CLC } & \text { Chemical Looping Cycle } \\ \text { LCOE } & \text { Levelized Cost of Electricity } \\ \text { ORC } & \text { Organic Rankine Cycle } \\ \text { SOFC } & \text { Solid Oxide Fuel Cell } \\ \text { ECA } & \text { Enhanced Capital Allowance } \\ \text { Mtoe } & \text { Million Tonnes of Oil Equivalent } \\ \text { ToSIA } & \text { Tool for Sustainability Impact Assessment } \\ S S_{C H P} & \text { CHP spark spread (\$) } \\ \text { Variables } & \\ \dot{W} & \text { Rate of } \text {, CHP power output }(\mathrm{W}) \\ \dot{Q} & \text { Rate of input heat (kJ/s) } \\ \dot{A} & \text { Rate of accumulation of energy } \\ \dot{C} & \text { Cost flow }\end{array}$




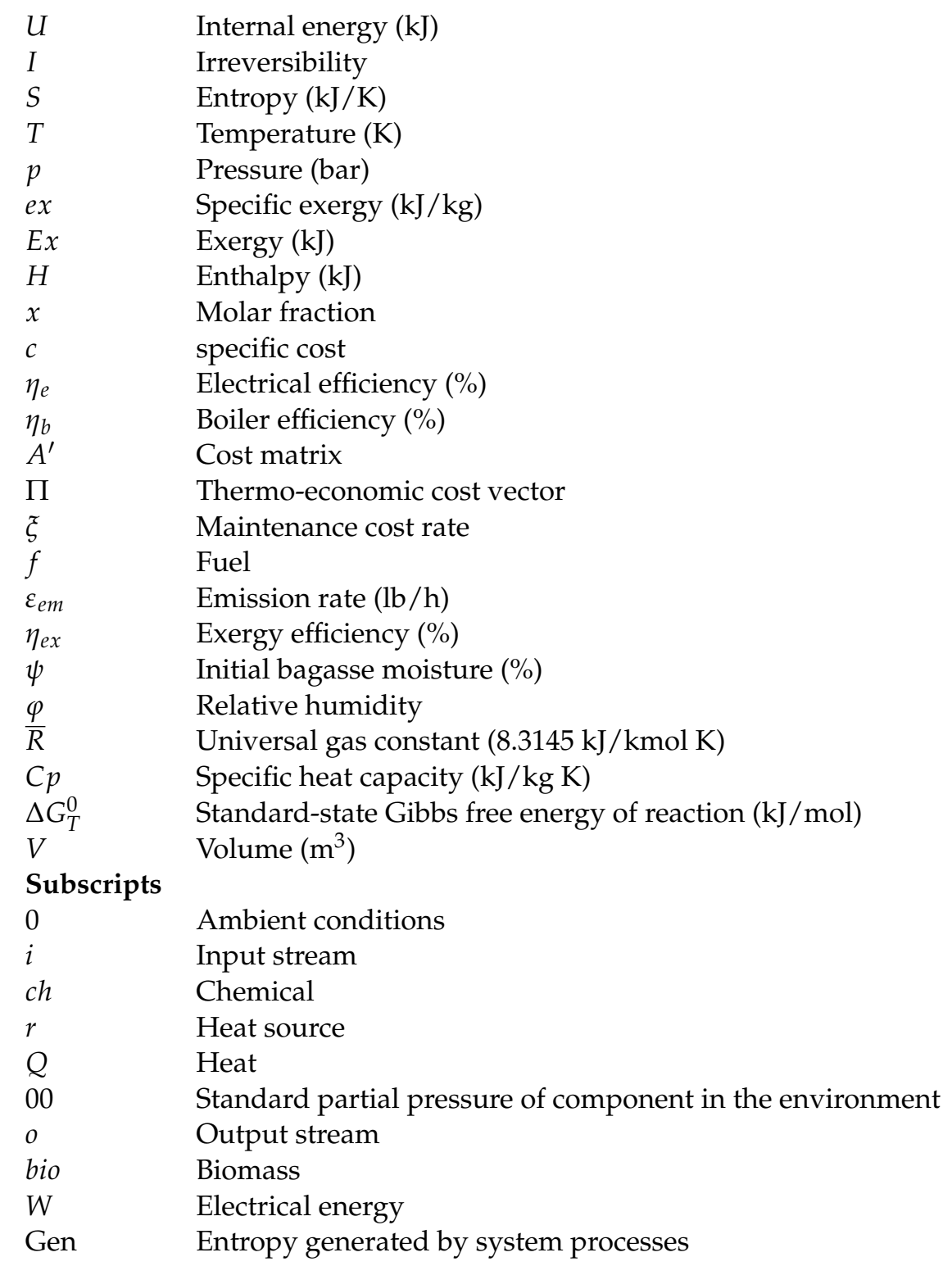

\section{References}

1. Delworth, T.L.; Mann, M.E. Observed and Simulated Multidecadal Variability in the Northern Hemisphere. Clim. Dyn. 2000, 16, 661-676. [CrossRef]

2. Hegerl, G.C.; Zwiers, F.W.; Braconnot, P.; Gillett, N.P.; Luo, Y.; Orsini, J.A.M.; Nicholls, N.; Penner, J.E.; Stott, P.A. Understanding and Attributing Climate Change. In Climate Change 2007: The Physical Science Basis; Contribution of Working Group I to the Fourth Assessment Report of the Intergovernmental Panel on Climate Change; Cambridge University Press: Cambridge, UK, 2007; Volume 80, pp. 213-238.

3. Mora, C.; Frazier, A.G.; Longman, R.J.; Dacks, R.S.; Walton, M.M.; Tong, E.J.; Sanchez, J.J.; Kaiser, L.R.; Stender, Y.O.; Anderson, J.M.; et al. The Projected Timing of Climate Departure from Recent Variability. Nature 2013, 502, 183-187. [CrossRef]

4. WHO. Greenhouse Gas Concentrations in Atmosphere Reach yet Another High; World Meteorological Organization (WMO): Geneva, Switzerland, 2019. Available online: https:/ / public.wmo.int/en/media/press-release/greenhouse-gas-concentrationsatmosphere-reach-yet-another-high (accessed on 3 June 2021).

5. Hannah Ritchie and Max Roser. $\mathrm{CO}_{2}$ and Greenhouse Gas Emissions. Published online at OurWorldInData.org. 2020. Available online: https: / / ourworldindata.org/co2-and-other-greenhouse-gas-emissions (accessed on 3 June 2021).

6. International Energy Agency (IEA). Global Energy and CO2 Status Report; The Latest Trends in Energy and Emissions in 2018; International Energy Agency: Paris, France, 2019. Available online: https://www.iea.org/reports/global-energy-co2-statusreport-2019 (accessed on 3 June 2021).

7. OECD/IEA. Market Report Series: Renewables 2018; Analysys and Forecasts to 2023; Executive Summary; Market Report Series; IEA Publication: Paris, France, 2018. Available online: https:/ /www.iea.org/reports/renewables-2018 (accessed on 3 June 2021). 
8. Asafu-Adjaye, J.; Byrne, D.; Alvarez, M. Dataset for Analysing the Relationships among Economic Growth, Fossil Fuel and Non-Fossil Fuel Consumption. Data Brief 2017, 10, 17-19. [CrossRef] [PubMed]

9. International Energy Agency (IEA). Energy efficiency and renewable energy. In World Energy Outlook 2018: The Future is Electrifying; IEA Publication: Paris, France, 2018. Available online: https:/ / www.iea.org/events/world-energy-outlook-2018-thefuture-is-electrifying (accessed on 3 June 2021).

10. Bhavanam, A.; Sastry, R.C. Biomass Gasification Processes in Downd Raft Fixed Bed Reactors: A Review. Int. J. Chem. Eng. Appl. 2011, 2, 425-433. [CrossRef]

11. IRENA-International Renewable Energy Agency Bioenergy. Available online: https://www.irena.org/bioenergy (accessed on 3 June 2021).

12. Nabipour Afrouzi, H.; Pamodha Wimalaratna, Y.; Ahmed, J.; Mehranzamir, K.; San, C.L.; Chin-Leong, W.; Bazlul, M.S. A Comprehensive Review on Available/Existing Renewable Energy Systems in Malaysia and Comparison of Their Capability of Electricity Generation in Malaysia. In Entropy and Exergy in Renewable Energy; IntechOpen: London, UK, 2021. Available online: https:/ / www.intechopen.com/online-first/a-comprehensive-review-on-available-existing-renewable-energy-systemsin-malaysia-and-comparison-of- (accessed on 3 June 2021). [CrossRef]

13. Banja, M.; Jégard, M. Renewable Technologies in the EU Electricity Sector: Trends and Projections. Analysis in the Framework of the EU 2030 Climate and Energy Strategy; EUR 28897 EN; JRC109254; Publications Office of the European Union: Luxembourg, 2017; ISBN 978-92-79-76903-0. [CrossRef]

14. Malico, I.; Nepomuceno Pereira, R.; Gonçalves, A.C.; Sousa, A.M.O. Current Status and Future Perspectives for Energy Production from Solid Biomass in the European Industry. Renew. Sustain. Energy Rev. 2019, 112, 960-977. [CrossRef]

15. Kummamuru, B. WBA Global Bioenergy Statistics 2018. World Bioenergy Assoc. 2018, 43. [CrossRef]

16. Calderon, C.; Colla, M.; Jossart, J.-M.; Hemeleers, N.; Martin, A.; Aveni, N.; Caferri, C. Statistical Report 2019; Report Biomass Supply; Bioenergy Europe: Brussels, Belgium, 2019. Available online: https:/ / bioenergyeurope.org/index.php?option=com_ attachments\&task=download\&id=737:Bioenergy-Lanscape-2019_FINAL_web (accessed on 3 June 2021).

17. Singh, P.; Singh, N. Political Economy of Bioenergy Transitions in Developing Countries: A Case Study of Punjab, India. World Dev. 2019, 124, 104630. [CrossRef]

18. Thumann, A.; Mehta, D.P. 9.1 Definition of "Cogeneration." In Handbook of Energy Engineering; Fairmont Press, Inc.: Atlanta, GA, USA, 2013; ISBN 978-0-88173-695-3.

19. Bagherian, M.A.; Mehranzamir, K. A Comprehensive Review on Renewable Energy Integration for Combined Heat and Power Production. Energy Convers. Manag. 2020, 224, 113454. [CrossRef]

20. Benam, M.R.; Madani, S.S.; Alavi, S.M.; Ehsan, M. Optimal Configuration of the CHP System Using Stochastic Programming. IEEE Trans. Power Deliv. 2015, 30, 1048-1056. [CrossRef]

21. Macadam, J.; Cox, J. Combined heat and power. In Chemical Engineer; Elsevier Ltd.: Amsterdam, The Netherlands, 2008 ; p. 32.

22. Houwing, M.; Negenborn, R.R.; de Schutter, B. Demand Response with Micro-CHP Systems. Proc. IEEE 2011, 99, 200-213. [CrossRef]

23. Yang, G.; Zheng, C.Y. Case of CCHP System in Shanghai. In Handbook of Energy Systems in Green Buildings; Wang, R., Zhai, X., Eds.; Springer: Berlin/Heidelberg, Germany, 2018. [CrossRef]

24. Carbon Trust. Introducing Combined Heat and Power; Carbon Trust: London, UK, 2010; p. 59.

25. Badea, N.; Ion, I.V.; Cazacu, N.; Paraschiv, L.; Paraschiv, S.; Caraman, S. Renewable Energy Sources for the mCCHP-SE-RES Systems. In Design for Micro-Combined Cooling, Heating and Power Systems: Stirling Engines and Renewable Power Systems; Badea, N., Ed.; Springer: London, UK, 2015; pp. 91-131, ISBN 978-1-4471-6254-4.

26. Janoska, P. Energy Transitions Indicators; IEA: Paris, France, 2019.

27. Eurostat. Combined Heat and Power (CHP) Data; Eurostat: Luxembourg, 2019.

28. Eurostat. CHP Data Capacity Generation 2015; Eurostat: Luxembourg, 2015.

29. Radenahmad, N.; Azad, A.T.; Saghir, M.; Taweekun, J.; Bakar, M.S.A.; Reza, M.S.; Azad, A.K. A Review on Biomass Derived Syngas for SOFC Based Combined Heat and Power Application. Renew. Sustain. Energy Rev. 2019, 119, 109560. [CrossRef]

30. Arsalis, A. A Comprehensive Review of Fuel Cell-Based Micro-Combined-Heat-and-Power Systems. Renew. Sustain. Energy Rev. 2019, 105, 391-414. [CrossRef]

31. Martinez, S.; Michaux, G.; Salagnac, P.; Bouvier, J.L. Micro-Combined Heat and Power Systems (Micro-CHP) Based on Renewable Energy Sources. Energy Convers. Manag. 2017, 154, 262-285. [CrossRef]

32. Murugan, S.; Horák, B. A Review of Micro Combined Heat and Power Systems for Residential Applications. Renew. Sustain. Energy Rev. 2016, 64, 144-162. [CrossRef]

33. Maghanki, M.M.; Ghobadian, B.; Najafi, G.; Galogah, R.J. Micro Combined Heat and Power (MCHP) Technologies and Applications. Renew. Sustain. Energy Rev. 2013, 28, 510-524. [CrossRef]

34. Situmorang, Y.A.; Zhao, Z.; Yoshida, A.; Abudula, A.; Guan, G. Small-Scale Biomass Gasification Systems for Power Generation (<200 kW Class): A Review. Renew. Sustain. Energy Rev. 2020, 117, 109486. [CrossRef]

35. Wegener, M.; Malmquist, A.; Isalgué, A.; Martin, A. Biomass-Fired Combined Cooling, Heating and Power for Small Scale Applications-A Review. Renew. Sustain. Energy Rev. 2018, 96, 392-410. [CrossRef]

36. Contino, F.; Moret, S.; Limpens, G.; Jeanmart, H. Whole-Energy System Models: The Advisors for the Energy Transition. Prog. Energy Combust. Sci. 2020, 81, 100872. [CrossRef] 
37. Codina Gironès, V.; Moret, S.; Peduzzi, E.; Nasato, M.; Maréchal, F. Optimal Use of Biomass in Large-Scale Energy Systems: Insights for Energy Policy. Energy 2017, 137, 789-797. [CrossRef]

38. Rajabi, M.; Mehrpooya, M.; Haibo, Z.; Huang, Z. Chemical Looping Technology in CHP (Combined Heat and Power) and CCHP (Combined Cooling Heating and Power) Systems: A Critical Review. Appl. Energy 2019, 253, 113544. [CrossRef]

39. Segurado, R.; Pereira, S.; Correia, D.; Costa, M. Techno-Economic Analysis of a Trigeneration System Based on Biomass Gasification. Renew. Sustain. Energy Rev. 2019, 103, 501-514. [CrossRef]

40. Ferreira, S.; Monteiro, E.; Brito, P.; Vilarinho, C. Biomass Resources in Portugal: Current Status and Prospects. Renew. Sustain. Energy Rev. 2017, 78, 1221-1235. [CrossRef]

41. Hosseini, S.E.; Wahid, M.A. Development of Biogas Combustion in Combined Heat and Power Generation. Renew. Sustain. Energy Rev. 2014, 40, 868-875. [CrossRef]

42. Buonomano, A.; Calise, F.; d'Accadia, M.D.; Palombo, A.; Vicidomini, M. Hybrid Solid Oxide Fuel Cells-Gas Turbine Systems for Combined Heat and Power: A Review. Appl. Energy 2015, 156, 32-85. [CrossRef]

43. Bagherian, M.A.; Mehranzamir, K.; Ahmed, J.; Nafea, M.; Nabipour-Afrouzi, H.; Wooi, C.; Beiranvand Pour, A.; Rezania, S.; Alizadeh, S.M. Techno-Economic Analysis of Direct Combustion and Gasification Systems for off-Grid Energy Supply: A Case for Organic Rankine Cycle and Dual Fluidized-Bed. IET Renew. Power Gener. 2021. [CrossRef]

44. Giampietro, M.; Mayumi, K.; Şorman, A.H. Energy Analysis for a Sustainable Future: Multi-Scale Integrated Analysis of Societal and Ecosystem Metabolism, 1st ed.; Mayumi, K., Şorman, A.H., ProQuest (Firm), Eds.; Routledge: London, UK; New York, NY, USA, 2013; ISBN 978-020-310-799-7.

45. Blok, K.; Nieuwlaar, E. Introduction to Energy Analysis; Taylor \& Francis: Abingdon, UK, 2016; ISBN 978-131-720-727-6.

46. Dincer, I.; Rosen, M.A. Chapter 1-Thermodynamic Fundamentals. In Exergy, 2nd ed.; Dincer, I., Rosen, M.A., Eds.; Elsevier: Amsterdam, The Netherlands, 2013; pp. 1-20, ISBN 978-0-08-097089-9.

47. Taner, T. Application of Exergy; IntechOpen: London, UK, 2018; ISBN 978-178-923-266-0.

48. Yang, S.; Yang, Q.; Qian, Y. A Composite Efficiency Metrics for Evaluation of Resource and Energy Utilization. Energy 2013, 61, 455-462. [CrossRef]

49. Dincer, I.; Rosen, M.A. Chapter 10-Exergy Analysis of Renewable Energy Systems. In Exergy; Dincer, I., Rosen, M.A., Eds.; Elsevier: Amsterdam, The Netherlands, 2007; pp. 163-228, ISBN 978-0-08-044529-8.

50. Terzi, R. Application of Exergy Analysis to Energy Systems, Application of Exergy, Tolga Taner; IntechOpen: London, UK, 2018. Available online: https:/ / www.intechopen.com/books/application-of-exergy/application-of-exergy-analysis-to-energy-systems (accessed on 3 June 2021). [CrossRef]

51. Marmolejo-Correa, D.; Gundersen, T. A Comparison of Exergy Efficiency Definitions with Focus on Low Temperature Processes. Energy 2012, 44, 477-489. [CrossRef]

52. Caliano, M.; Bianco, N.; Graditi, G.; Mongibello, L. Design Optimization and Sensitivity Analysis of a Biomass-Fired Combined Cooling, Heating and Power System with Thermal Energy Storage Systems. Energy Convers. Manag. 2017, 149, 631-645. [CrossRef]

53. Damirchi, H.; Najafi, G.; Alizadehnia, S.; Mamat, R.; Nor Azwadi, C.S.; Azmi, W.H.; Noor, M.M. Micro Combined Heat and Power to Provide Heat and Electrical Power Using Biomass and Gamma-Type Stirling Engine. Appl. Therm. Eng. 2016, 103, 1460-1469. [CrossRef]

54. Camporeale, S.M.; Fortunato, B.; Torresi, M.; Turi, F.; Pantaleo, A.M.; Pellerano, A. Part Load Performance and Operating Strategies of a Natural Gas-Biomass Dual Fueled Microturbine for Combined Heat and Power Generation. J. Eng. Gas Turbines Power 2015, 137. [CrossRef]

55. Li, C.Y.; Deethayat, T.; Wu, J.Y.; Kiatsiriroat, T.; Wang, R.Z. Simulation and Evaluation of a Biomass Gasification-Based Combined Cooling, Heating, and Power System Integrated with an Organic Rankine Cycle. Energy 2018, 158, 238-255. [CrossRef]

56. Kotas, T.J. (Ed.) Appendix A-Chemical exergy and enthalpy of devaluation. In The Exergy Method of Thermal Plant Analysis; Butterworth-Heinemann: Oxford, UK, 1985; pp. 236-262, ISBN 978-0-408-01350-5.

57. Mujumdar, A.S. A Review of: “Exergy Method-Technical and Ecological Applications". Dry. Technol. 2005, 23, 2523-2524. Available online: https://www.tandfonline.com/doi/abs/10.1080/07373930500341773?journalCode=ldrt20 (accessed on 3 June 2021). [CrossRef]

58. Rosen, M.A. Exergy: Analysis. In Encyclopedia of Energy Engineering and Technology, 2nd ed.; Informa UK Limited: London, UK, 2014; pp. 683-691, ISBN 978-047-003-037-0.

59. Flórez-Orrego, D.; Nascimento Silva, F.; de Oliveira Junior, S. Syngas Production with Thermo-Chemically Recuperated Gas Expansion Systems: An Exergy Analysis and Energy Integration Study. Energy 2019, 178, 293-308. [CrossRef]

60. Flórez-Orrego, D.; Maréchal, F.; de Oliveira Junior, S. Comparative Exergy and Economic Assessment of Fossil and Biomass-Based Routes for Ammonia Production. Energy Convers. Manag. 2019, 194, 22-36. [CrossRef]

61. Karellas, S.; Braimakis, K. Energy-Exergy Analysis and Economic Investigation of a Cogeneration and Trigeneration ORC-VCC Hybrid System Utilizing Biomass Fuel and Solar Power. Energy Convers. Manag. 2016, 107, 103-113. [CrossRef]

62. Wang, Q.; Wu, W.; He, Z. Thermodynamic Analysis and Optimization of a Novel Organic Rankine Cycle-Based Micro-Scale Cogeneration System Using Biomass Fuel. Energy Convers. Manag. 2019, 198, 111803. [CrossRef]

63. Yang, Y.; Brammer, J.G.; Wright, D.G.; Scott, J.A.; Serrano, C.; Bridgwater, A.V. Combined Heat and Power from the Intermediate Pyrolysis of Biomass Materials: Performance, Economics and Environmental Impact. Appl. Energy 2017, 191, 639-652. [CrossRef] 
64. Najafi, G.; Hoseini, S.S.; de Goey, L.P.H.; Yusaf, T. Optimization of Combustion in Micro Combined Heat and Power (MCHP) System with the Biomass-Stirling Engine Using $\mathrm{SiO}_{2}$ and $\mathrm{Al}_{2} \mathrm{O}_{3}$ Nanofluids. Appl. Thermal Eng. 2020, 169. [CrossRef]

65. Morrone, P.; Algieri, A.; Castiglione, T. Hybridisation of Biomass and Concentrated Solar Power Systems in Transcritical Organic Rankine Cycles: A Micro Combined Heat and Power Application. Energy Convers. Manag. 2019, 180, 757-768. [CrossRef]

66. Campo, P.; Benitez, T.; Lee, U.; Chung, J.N. Modeling of a Biomass High Temperature Steam Gasifier Integrated with Assisted Solar Energy and a Micro Gas Turbine. Energy Convers. Manag. 2015, 93, 72-83. [CrossRef]

67. Zhu, Y.; Li, W.; Li, J.; Li, H.; Wang, Y.; Li, S. Thermodynamic Analysis and Economic Assessment of Biomass-Fired Organic Rankine Cycle Combined Heat and Power System Integrated with $\mathrm{CO}_{2}$ Capture. Energy Convers. Manag. 2020, $204,112310$. [CrossRef]

68. Karimi, M.H.; Chitgar, N.; Emadi, M.A.; Ahmadi, P.; Rosen, M.A. Performance Assessment and Optimization of a Biomass-Based Solid Oxide Fuel Cell and Micro Gas Turbine System Integrated with an Organic Rankine Cycle. Int. J. Hydrogen Energy 2020. [CrossRef]

69. Wang, J.; Yang, Y. Energy, Exergy and Environmental Analysis of a Hybrid Combined Cooling Heating and Power System Utilizing Biomass and Solar Energy. Energy Convers. Manag. 2016, 124, 566-577. [CrossRef]

70. Authayanun, S.; Hacker, V. Energy and Exergy Analyses of a Stand-Alone HT-PEMFC Based Trigeneration System for Residential Applications. Energy Convers. Manag. 2018, 160, 230-242. [CrossRef]

71. Moradi, R.; Marcantonio, V.; Cioccolanti, L.; Bocci, E. Integrating Biomass Gasification with a Steam-Injected Micro Gas Turbine and an Organic Rankine Cycle Unit for Combined Heat and Power Production. Energy Convers. Manag. 2020, $205,112464$. [CrossRef]

72. Salman, C.A.; Naqvi, M.; Thorin, E.; Yan, J. Impact of Retrofitting Existing Combined Heat and Power Plant with Polygeneration of Biomethane: A Comparative Techno-Economic Analysis of Integrating Different Gasifiers. Energy Convers. Manag. 2017, 152, 250-265. [CrossRef]

73. Prakash, M.; Sarkar, A.; Sarkar, J.; Mondal, S.S.; Chakraborty, J.P. Proposal and Design of a New Biomass Based Syngas Production System Integrated with Combined Heat and Power Generation. Energy 2017, 133, 986-997. [CrossRef]

74. Galanti, L.; Franzoni, A.; Traverso, A.; Massardo, A.F. Existing Large Steam Power Plant Upgraded for Hydrogen Production. Appl. Energy 2011, 88, 1510-1518. [CrossRef]

75. Sharma, A.; Shinde, Y.; Pareek, V.; Zhang, D. Process Modelling of Biomass Conversion to Biofuels with Combined Heat and Power. Bioresour. Technol. 2015, 198, 309-315. [CrossRef]

76. Beiron, J.; Montañés, R.M.; Normann, F.; Johnsson, F. Dynamic Modeling for Assessment of Steam Cycle Operation in Waste-Fired Combined Heat and Power Plants. Energy Convers. Manag. 2019, 198, 111926. [CrossRef]

77. Gustavsson, C.; Hulteberg, C. Co-Production of Gasification Based Biofuels in Existing Combined Heat and Power PlantsAnalysis of Production Capacity and Integration Potential. Energy 2016, 111, 830-840. [CrossRef]

78. Balaji, C. Essentials of Thermal System Design and Optimization; Ane Books: New Delhi, India; CRC Press: Boca Raton, FL, USA, 2011; ISBN 978-143-989-154-4.

79. Bagherian, M.A.; Mehranzamir, K.; Ahmed, J.; Nafea, M.; Nabipour-Afrouzi, H.; Wooi, C.-1. Development of Biomass-Fueled Cogeneration Systems for Off-Grid Electrification. In Proceedings of the 2nd International Conference on Smart Power \& Inter-net Energy Systems (SPIES), Bangkok, Thailand, 15-18 September 2020; pp. 566-571. [CrossRef]

80. Bagherian, M.A.; Mehranzamir, K.; Pour, A.B.; Rezania, S.; Taghavi, E.; Nabipour-Afrouzi, H.; Dalvi-Esfahani, M.; Alizadeh, S.M. Classification and Analysis of Optimization Techniques for Integrated Energy Systems Utilizing Renewable Energy Sources: A Review for CHP and CCHP Systems. Processes 2021, 9, 339. [CrossRef]

81. Rao, S.S. Engineering Optimization: Theory and Practice; Wiley: Hoboken, NJ, USA, 2019; ISBN 978-111-945-471-7.

82. Arora, J.S. Chapter 6-Optimum Design: Numerical Solution Process and Excel Solver. In Introduction to Optimum Design, 4th ed.; Arora, J.S., Ed.; Academic Press: Boston, MA, USA, 2017; pp. 237-278, ISBN 978-0-12-800-806-5.

83. Frangopoulos, C.A. Recent Developments and Trends in Optimization of Energy Systems. Energy 2018, 164, 1011-1020. [CrossRef]

84. Deb, K. Introduction to Genetic Algorithms for Engineering Optimization. In New Optimization Techniques in Engineering; Springer: Berlin/Heidelberg, Germany, 2004; pp. 13-51, ISBN 978-3-540-39930-8.

85. Demirel, Y. 5-Thermoeconomics. In Nonequilibrium Thermodynamics, 2nd ed.; Demirel, Y., Ed.; Elsevier Science B.V.: Amsterdam, The Netherlands, 2007; pp. 275-318, ISBN 978-0-444-53079-0.

86. Demirel, Y. Thermodynamic Analysis. Arab. J. Sci. Eng. 2013, 38, 221-249. [CrossRef]

87. Demirel, Y.; Gerbaud, V. Thermoeconomics. In Nonequilibrium Thermodynamics; Demirel, Y., Gerbaud, V., Eds.; Elsevier: Amsterdam, The Netherlands, 2019; pp. 267-294, ISBN 978-0-444-64112-0.

88. Zhang, X.; Zeng, R.; Mu, K.; Liu, X.; Sun, X.; Li, H. Exergetic and Exergoeconomic Evaluation of Co-Firing Biomass Gas with Natural Gas in CCHP System Integrated with Ground Source Heat Pump. Energy Convers. Manag. 2019, 180, 622-640. [CrossRef]

89. Li, C.Y.; Wu, J.Y.; Chavasint, C.; Sampattagul, S.; Kiatsiriroat, T.; Wang, R.Z. Multi-Criteria Optimization for a Biomass GasificationIntegrated Combined Cooling, Heating, and Power System Based on Life-Cycle Assessment. Energy Convers. Manag. 2018, 178, 383-399. [CrossRef]

90. Baghernejad, A.; Yaghoubi, M.; Jafarpur, K. Exergoeconomic Comparison of Three Novel Trigeneration Systems Using SOFC, Biomass and Solar Energies. Appl. Thermal Eng. 2016, 104, 534-555. [CrossRef] 
91. Di Fraia, S.; Massarotti, N.; Vanoli, L.; Costa, M. Thermo-Economic Analysis of a Novel Cogeneration System for Sewage Sludge Treatment. Energy 2016, 115, 1560-1571. [CrossRef]

92. Gandiglio, M.; Saberi Mehr, A.; MosayebNezhad, M.; Lanzini, A.; Santarelli, M. Solutions for Improving the Energy Efficiency in Wastewater Treatment Plants Based on Solid Oxide Fuel Cell Technology. J. Clean. Prod. 2020, 247, 119080. [CrossRef]

93. Prando, D.; Renzi, M.; Gasparella, A.; Baratieri, M. Monitoring of the Energy Performance of a District Heating CHP Plant Based on Biomass Boiler and ORC Generator. Appl. Therm. Eng. 2015, 79, 98-107. [CrossRef]

94. Díez-Montero, R.; Solimeno, A.; Uggetti, E.; García-Galán, M.J.; García, J. Feasibility Assessment of Energy-Neutral MicroalgaeBased Wastewater Treatment Plants under Spanish Climatic Conditions. Process. Saf. Environ. Prot. 2018, 119, 242-252. [CrossRef]

95. Wang, J.; Mao, T.; Sui, J.; Jin, H. Modeling and Performance Analysis of CCHP (Combined Cooling, Heating and Power) System Based on Co-Firing of Natural Gas and Biomass Gasification Gas. Energy 2015, 93, 801-815. [CrossRef]

96. Wang, J.; Ma, C.; Wu, J. Thermodynamic Analysis of a Combined Cooling, Heating and Power System Based on Solar Thermal Biomass Gasification ‘s. Appl. Energy 2019, 247, 102-115. [CrossRef]

97. Frangopoulos, C.A. Exergy, Energy System Analysis and Optimization-Volume II: Thermoeconomic Analysis Modeling, Simulation and Optimization in Energy Systems; Eolss Publishers Company Limited: Oxford, UK, 2009. Available online: https://play.google.com/ store/books/details/Exergy_Energy_System_Analysis_and_Optimization_Vol?id=udGUCwAAQBAJ\&hl=en (accessed on 3 June 2021).

98. Abusoglu, A.; Kanoglu, M. Exergoeconomic Analysis and Optimization of Combined Heat and Power Production: A Review. Renew. Sustain. Energy Rev. 2009, 13, 2295-2308. [CrossRef]

99. Lozano, M.A.; Valero, A. Theory of the Exergetic Cost. Energy 1993, 18, 939-960. [CrossRef]

100. Szargut, J.; Morris, D.R.; Steward, F.R. Exergy Analysis of Thermal, Chemical, and Metallurgical Processes; Hemisphere Publishing: New York, NY, USA, 1987.

101. Valero, A.; Lozano, M.A. An Introduction to Thermoeconomics; Cambridge, University Press: Cambridge, UK, 1997; Volume 9, ISBN 020-341-872-7.

102. Tsatsaronis, G.; Moran, M.J. Exergy-Aided Cost Minimization. Energy Convers. Manag. 1997, 38, 1535-1542. [CrossRef]

103. Darabadi Zareh, A.; Khoshbakhti Saray, R.; Mirmasoumi, S.; Bahlouli, K. Extensive Thermodynamic and Economic Analysis of the Cogeneration of Heat and Power System Fueled by the Blend of Natural Gas and Biogas. Energy Convers. Manag. 2018, 164, 329-343. [CrossRef]

104. Lythcke-Jørgensen, C.; Haglind, F. Design Optimization of a Polygeneration Plant Producing Power, Heat, and Lignocellulosic Ethanol. Energy Convers. Manag. 2015, 91, 353-366. [CrossRef]

105. Beith, R. (Ed.) Small and Micro Combined Heat and Power (CHP) Systems: Advanced Design, Performance, Materials and Applications; Woodhead Publishing: Cambridge, UK, 2011; Volume 18, ISBN 978-184-569-795-2.

106. Frangopoulos, C.A. Optimization Methods for Energy Systems. In Exergy, Energy System Analysis and Optimization; EOLSS Publications: Abu Dhabi, United Arab Emirates, 2017; Volume II, pp. 233-258, ISBN 978-1-84826-165-5. Available online: http:/ / www.eolss.net/sample-chapters / c08/ (accessed on 3 June 2021).

107. Al-Sulaiman, F.A.; Dincer, I.; Hamdullahpur, F. Thermoeconomic Optimization of Three Trigeneration Systems Using Organic Rankine Cycles: Part II-Applications. Energy Convers. Manag. 2013, 69, 209-216. [CrossRef]

108. Al-Sulaiman, F.A.; Dincer, I.; Hamdullahpur, F. Thermoeconomic Optimization of Three Trigeneration Systems Using Organic Rankine Cycles: Part I-Formulations. Energy Convers. Manag. 2013, 69, 199-208. [CrossRef]

109. Dinçer, I. Exergy: Energy, Environment and Sustainable Development, 2nd ed.; Dincer, I., Rosen, M.A., Eds.; Elsevier: Oxford, UK, 2012; ISBN 978-008-097-090-5.

110. Naikwadi, K.P.; Karasek, F.W. Chapter 24 Environmental analysis. In Chromatography, 5th ed.; Heftmann, E., Ed.; Journal of Chromatography Library; Elsevier: Amsterdam, The Netherlands, 1992; Volume 51, pp. B555-B582.

111. Cushion, E.; Whiteman, A.; Dieterle, G. Bioenergy Development: Issues and Impacts for Poverty and Natural Resource Management; Agriculture and Rural Development Series; World Bank Publications: Washington, DC, USA, 2009; ISBN 978-082-138-129-8.

112. Maroušek, J.; Strunecký, O.; Stehel, V. Biochar Farming: Defining Economically Perspective Applications. Clean Technol. Environ. Policy 2019, 21, 1389-1395. [CrossRef]

113. House, K.Z.; Baclig, A.C.; Ranjan, M.; van Nierop, E.A.; Wilcox, J.; Herzog, H.J. Economic and Energetic Analysis of Capturing $\mathrm{CO}_{2}$ from Ambient Air. Proc. Natl. Acad. Sci. USA 2011, 108, 20428. [CrossRef]

114. Brown, R.C. Biorenewable Resources Engineering New Products from Agriculture, 2nd ed.; Brown, R.C., Brown, T.R., Eds.; Wiley Blackwell: Chichester, UK, 2014; ISBN 978-111-852-493-0.

115. Sacchelli, S. 9-Social, economic, and environmental impacts of biomass and biofuel supply chains. In Biomass Supply Chains for Bioenergy and Biorefining; Holm-Nielsen, J.B., Ehimen, E.A., Eds.; Woodhead Publishing: Cambridge, UK, 2016; pp. 191-213, ISBN 978-1-78242-366-9.

116. Ashter, S.A. 13-Environmental impact of biomass conversion. In Technology and Applications of Polymers Derived from Biomass; Ashter, S.A., Ed.; Plastics Design Library; William Andrew Publishing: Norwich, NY, USA, 2018; pp. 249-259, ISBN 978-0-32351115-5.

117. Jagger, P.; Kittner, N. Deforestation and Biomass Fuel Dynamics in Uganda. Biomass Bioenergy 2017, 105, 1-9. [CrossRef]

118. Bajpai, P. Chapter 10-Energy-related environmental issues. In Biomass to Energy Conversion Technologies; Bajpai, P., Ed.; Elsevier: Amsterdam, The Netherlands, 2020; pp. 205-216, ISBN 978-0-12-818400-4. 
119. Lazarus, M.; von Hippel, D. A Guide to Environmental Analysis for Energy Planners; Stockholm Environment Institute: Boston, MA, USA, 1995.

120. Balaman, Ş.Y. Chapter 4-Sustainability Issues in Biomass-Based Production Chains. In Decision-Making for Biomass-Based Production Chains; Balaman, S..Y., Ed.; Academic Press: Cambridge, MA, USA, 2019; pp. 77-112, ISBN 978-0-12-814-278-3.

121. Tojo, S.; Hirasawa, T. Research Approaches to Sustainable Biomass Systems; Elsevier Science: Amsterdam, The Netherlands, 2013; ISBN 978-012-404-683-2.

122. Maraver, D.; Sin, A.; Sebastián, F.; Royo, J. Environmental Assessment of CCHP (Combined Cooling Heating and Power) Systems Based on Biomass Combustion in Comparison to Conventional Generation. Energy 2013, 57, 17-23. [CrossRef]

123. ISO. Environmental Managment, Life Cycle Anaysis, Principles and Framework; ISO: Geneva, Switzerland, 2006.

124. ISO. ISO/TS 14072: Environmental Management_Life Cycle Assessment_Requirements and Guidelines for Organizational Life Cycle Assessment; International Organization for Standardization: Geneva, Switzerland, 2014.

125. Havukainen, J.; Nguyen, M.T.; Väisänen, S.; Horttanainen, M. Life Cycle Assessment of Small-Scale Combined Heat and Power Plant: Environmental Impacts of Different Forest Biofuels and Replacing District Heat Produced from Natural Gas. J. Cleaner Prod. 2018, 172, 837-846. [CrossRef]

126. Tagliaferri, C.; Evangelisti, S.; Clift, R.; Lettieri, P. Life Cycle Assessment of a Biomass CHP Plant in UK: The Heathrow Energy Centre Case. Chem. Eng. Res. Des. 2018, 133, 210-221. [CrossRef]

127. Muthu, S.S. 6-Estimating the overall environmental impact of textile processing: Life cycle assessment (LCA) of textile products. In Assessing the Environmental Impact of Textiles and the Clothing Supply Chain; Muthu, S.S., Ed.; Woodhead Publishing: Cambridge, UK, 2014; pp. 105-131, ISBN 978-1-78242-104-7.

128. Maier, J.M.; Sowlati, T.; Salazar, J. Life Cycle Assessment of Forest-Based Biomass for Bioenergy: A Case Study in British Columbia, Canada. Resour. Conserv. Recycl. 2019, 146, 598-609. [CrossRef]

129. Khasreen, M.M.; Banfill, P.F.G.; Menzies, G.F. Life-Cycle Assessment and the Environmental Impact of Buildings: A Review. Sustainability 2009, 1, 674-701. [CrossRef]

130. Karvonen, J.; Kunttu, J.; Suominen, T.; Kangas, J.; Leskinen, P.; Judl, J. Integrating Fast Pyrolysis Reactor with Combined Heat and Power Plant Improves Environmental and Energy Efficiency in Bio-Oil Production. J. Cleaner Prod. 2018, 183, 143-152. [CrossRef]

131. Roy, D.; Samanta, S.; Ghosh, S. Techno-Economic and Environmental Analyses of a Biomass Based System Employing Solid Oxide Fuel Cell, Externally Fired Gas Turbine and Organic Rankine Cycle. J. Cleaner Prod. 2019, 225, 36-57. [CrossRef]

132. Mortazaei, M.; Rahimi, M. A Comparison between Two Methods of Generating Power, Heat and Refrigeration via Biomass Based Solid Oxide Fuel Cell: A Thermodynamic and Environmental Analysis. Energy Convers. Manag. 2016, 126, 132-141. [CrossRef]

133. Li, H.; Zhang, X.; Liu, L.; Zeng, R.; Zhang, G. Exergy and Environmental Assessments of a Novel Trigeneration System Taking Biomass and Solar Energy as Co-Feeds. Appl. Thermal Eng. 2016, 104, 697-706. [CrossRef]

134. Gholamian, E.; Zare, V.; Mousavi, S.M. Integration of Biomass Gasification with a Solid Oxide Fuel Cell in a Combined Cooling, Heating and Power System: A Thermodynamic and Environmental Analysis. Int. J. Hydrogen Energy 2016, 41, 20396-20406. [CrossRef]

135. Su, B.; Han, W.; Zhang, X.; Chen, Y.; Wang, Z.; Jin, H. Assessment of a Combined Cooling, Heating and Power System by Synthetic Use of Biogas and Solar Energy. Appl. Energy 2018, 229, 922-935. [CrossRef]

136. Chicco, G.; Mancarella, P. Assessment of the Greenhouse Gas Emissions from Cogeneration and Trigeneration Systems. Part I: Models and Indicators. Energy 2008, 33, 410-417. [CrossRef]

137. Uris, M.; Linares, J.I.; Arenas, E. Feasibility Assessment of an Organic Rankine Cycle (ORC) Cogeneration Plant (CHP/CCHP) Fueled by Biomass for a District Network in Mainland Spain. Energy 2017, 133, 969-985. [CrossRef] 